\title{
Örgütlü Dinî Gruplarda Hegemonik Dönüşüm Nurculuktan Post-Nurculuğa, Cemaatten Örgüte Gülenist Yapının Sosyolojik Kodları
}

\author{
Celaleddin Çelik
}

\begin{abstract}
Öz: Bu makale, başlangıçta dinî bir grup olarak ortaya çıkan, ancak önce kamusal alanda örgütlenen ve zamanla siyasal alanda hegemonik bir güç haline gelen Gülenist cemaatin örgütsel yapıya dönüşümünü sosyolojik açıdan çözümlemeyi amaçlamıştır. Modern dünyada dinî gruplar yeni görünüm, işlev ve temsillerle faaliyetlerini çeşitlendirmektedir. Kamusal alan, yeni dinî grupların ve hareketlerin piyasa modeli içerisinde rekabet etmelerine imkân vermektedir. Ancak sivil demokratik alanın daraldığı dönemlerde illegal örgütlenme stratejilerini benimseyen dinî yapılar, demokratikleşme süreçlerinde bu özelliklerini hegemonik bir araca dönüştürebilmektedirler. Nur geleneğine dayalı cemaat kalıpları içinde ortaya çıkan Gülenist hareket, başlangıcından itibaren sosyal organizasyonlar içinde ve bürokratik yapılarda örgütlenme yolunu seçmiştir. Hareket içi söyleminde dinî nosyonu kullanan yapının, grup dışına yönelik söyleminde sivil sosyal araçları ve bürokratik kritik mekanizmaları bir hegemonik araç olarak seçmesi, toplumsal düzeyde çok boyutlu etkilere yol açmışıtır. Uluslararası boyutlu küresel bir ağ yapısına taşınan yapının sosyoloji literatürüne darbeyle ilişkili bir sürecin aktörü olarak yerleşmesi, temel ayırt edici bir farklılık olarak kodlanmıştır.
\end{abstract}

Anahtar Kelimeler: Cemaat, Dinî Grup, Paralel Yapı, Gülenist Yapı, Darbe, Örgütlü Dinî Yapı, FETÖ.

\begin{abstract}
This essay aims to explain sociologically the transformation of the Gülenist community emerging as a religious group then an organizational structure through organizing in the public arena and gradually on to a hegemonic power in the political arena. In the modern world, religious groups diversify their activities with new looks, functions and representations. The public sphere allows new religious groups and movements to compete within the market model. However, religious structures that adopt illegal organizing strategies during periods of civilian democratic decline can turn these features into a hegemonic rite in the democratization processes. The Gulenist movement, which emerged in congregational forms based on the tradition of Nur, chose to develop into social organizations and bureaucratic structures. The use of religious notions in the in-motion discourse and the selection of civil social tools and bureaucratic critical mechanisms as a hegemonic tool in the discourse towards the outside of the group led to multidimensional influences at the social level. The establishment of the Gülenist movement as a global network of international dimensions which lead the sociological literature to code this movement as a continuing actor of the coup attempt is a fundamentally distinctive difference.
\end{abstract}

Keywords: Community, Religious Group, Parallel Structures, Gulenist Structure, Coup, Organized Religious Structure, FETO.

\footnotetext{
* Bu yazı, 15 Kasım 2014 tarihinde İstanbul'da İlmi Etüdler Derneği (ILEM) tarafindan düzenlenen “Türkiye’de Dinî Grupların Dönüşümü" isimli çalıştayda "Nurculuktan Post-Nurculuğa, Cemaatten Paralel Yapıya Dönüşüm" başliğı altında bildiri olarak sunulmuştur. Süreç içerisinde yayına dönüşmeyen Çalıştay bildirisi, 15 Temmuz Darbe Girişimi sonrası yeni verilerle desteklenerek makaleye dönüştürülmüştür.
}

Prof. Dr., Erciyes Üniversitesi. celikcela@gmail.com.

(C) İlmi Etüdler Derneği

DOI: 10.12658/human.society.7.13.M0203

İnsan \& Toplum, 7(1), 2017, 25-67.

insanvetoplum.org 


\section{Giriş: Gülenist Yapının İdeolojik Arka Planı}

Bu yazı, başlangıçta bir dinî cemaat olarak tanımlanan ancak süreç içerisinde, bilinen dinî grup kategorilerini aşarak örgütsel bir yapıya dönüşen Gülenist hareketin sosyolojik analizini amaç edinmektedir. Makalede, Fetullah Gülen'in görüşleri yerine cemaatin ideolojisi, din anlayışı, sivil, sosyal, siyasal ve kurumsal alanlardaki faaliyetleri ile organizasyonel dönüşümleri eksene alınmıştır.

Köken itibariyle kendini Nur hareketi içinde temellendiren cemaat, zamanla F. Gülen etrafında oluşturulan metinler ve genişleyen organizasyonlar ağıyla, giderek, Nurculuktan müstakil bir yapıya dönüşmüştür. Teoride Nurculuğa özgü metinsel, ezoterik, 'mehdici' bazı inanç ve dil unsurlarını paylaşan cemaat, zamanla, referans aldığı ana gövdeden uzaklaşarak, kendi ideolojik ve örgütsel yapısına gelişerek evrilmiştir. Gülenist yapının bu bağlamda diğer dinî gruplardan ayrılan en önemli yönü, benimsediği "aksiyon"cu tarza bağlı olarak, kamusal alanda sosyal ve ekonomik sermayeyi temerküz etmeye yönelik bir strateji izlemesi, kültürel, kurumsal ağlar ile bürokratik kurumlarda yapilanmaya yönelmesidir.

Gülenist cemaat yaklaşık kırk yıllık bir süreçte kamusal, bürokratik ve resmî alanlarda eğitim, ekonomi, siyaset, medya, sivil toplum, dershaneler, dernekler ve vakıflar ile kritik devlet kurumları üzerinden sağladığı çok yönlü nüfuz ile toplumsal alanda etkili bir güç olmayı hedeflemiştir. Örgüt her ne kadar mensupları nezdinde ve kamuoyundaki tanımında "cemaat" olarak bilinse de, bu yazıda hareketin sosyolojik anlamda artık bir cemaatten ziyade "örgütlü dinsel yapı" ya da "paralel yapı" gibi kavramlaştırmaları tercih edilecektir. Metinde kullanılan "örgütlü dinsel yapı"1 kavramıla ise hareketin gerçekte dinden mülhem ya da ona dayalı değil, aksine onu kullanan ve araçsallaştıran bir grup oluşu ima edilmektedir.

Paralel yapının süreç içerisinde taktik ve stratejilerine göre kamusal, kurumsal ve bürokratik alanda sağladığı hegemonik güç, grubun bilinen zihnî ve ideolojik yaklaşımlarında, örgütsel tavır ve eylemlerinde de dönüşüme yol açmıştır. Nitekim başlangıçta dinî cemaat kodlarını benimseyen ve kamuya açık dilinde bunu işleyen Gülenist örgüt, zamanla sivil, kamusal, kurumsal ve toplumsal alanda izlediği stratejiye uygun olarak hem büyük çaplı kazanımlar edinmiş hem de başlangıçtaki ideolojik kodlarında ve örgütlenme tarzında sürekli değişime gitmiştir.

1 Kavramın kullanımı ve içeriği konusunda Prof. Dr. Erdal Baykan (NEÜ, Felsefe Öğr. Üyesi)'ın katkısını burada anma gereğini hissediyorum. Öte yandan, sosyolojik bağlamına rağmen, Gülenist yapıyla ilgili yazılarda genellikle grubun ayırt edici ifadesi olarak "cemaat" kavramı yine paralel yapıya atfen kullanılmaktadır. Bu sebeple, metinde geçen cemaat kavramı da, dinî bir gruptan ziyade, Gülenist yapıyı ifade etmek için kullanılmaktadır. 
Grubun kamuya açık yüzünde bu değişimin en önemli göstergesi, hareketi tanımlayan kavramların değişkenliğinde izlenmiştir. Nitekim kendi öz tanımlarında başlangıçta "cemaat" olarak dile getirilen yapının, uluslararası eğitim, finans ve ilişkiler ağında bir güç haline gelmeye başlamasıyla "Gönüllüler Hareketi”, "Adanmışlar", "Hizmet Hareketi” ya da kısaca "Hizmet” gibi kavramların dolaşıma sokulması, gerçekte toplumsal ve yasal meşruiyet için kullanılan bir argüman olmuştur. Ancak yapının toplumsal tartışma alanında, özellikle 17 Aralık öncesinde ve hemen akabinde aşırı siyasallaşma eğilimine rağmen, yaygın bir şekilde "cemaat" kavramıyla ele alınması, gerçekte bir cemaat olarak kabullenilmesinden ziyade, kastedilen yapıya işaret etmek içindir denebilir. Grubun "paralel yapı”ya dönüşen tanımı ise 17-25 Aralık 2013 Darbe Girişimi’nde ve daha sonra 19 Ocak 2014 Mit Tirları Operasyonu'nda ortaya çıkan rolü nedeniyle resmî söylemde tescillenmiş, öte yandan toplumsal bağlamda da yaygın kabul görmüştür.

Gülenist yapıyı inceleyen bir çalışmanın muhtemel zorlukları sadece isim ve tanımlama konusuyla sınırlı değildir. Belki de bu bakımdan en önemli sorun, cemaatle ilgili çalışmaların önemli bir kısmının yine cemaat tarafından sübvanse edilmesi, desteklenmesi ve sipariş olarak üretilmesi nedeniyle nesnel verilere ve yorumlara ulaşma sıkıntısıdır. Öte yandan bu yazı, 90’lı yıllardan sonra kamusal alanda ve devletin kritik kurumlarında örgütlenmesiyle gündeme gelen, ancak özellikle 1725 Aralık 2013 sonrasında darbeci girişimleri nedeniyle tartışma ve çatışmaların odağında yer alan yapının ülke gündemini altüst ettiği bir dönemde inşa edildi. Ancak sosyal analizlerin bazen toplumsal süreçlerin bitmesini bekleme lüksü yoktur ve aslında Gülenist yapının örgütsel gelişimine yönelik böyle bir analiz, hem zihniyet ve stratejilerdeki dönüşümü açıklamaya hem de gelecekte görülebilecek bu tür oluşumları tahmine yönelik firsatlar içerir. Bu bakımlardan cemaatin yapısal ve ideolojik kritiği için öncelikli olarak düşünsel kodların ve stratejik yönelimlerin kaynaklandığı Nur geleneğiyle ilişkisine dikkat çekmek istiyoruz.

\section{Modern Epistemolojinin Araçsallaştırılması}

Bir dinî grup olarak Nurculuğun ortaya çıkışı ile İslam dünyasının modernlikle karşılaşması arasında bir etkileşim bulunmaktadır. Nurculuk, hemen her alanda üstünlüğü ele geçiren Batılı modernlik karşısında İslam geleneğinin etkisizleşmesine yönelik bir tepkiyi içerir. Ancak bu itiraz, temelde modern epistemolojiyi reddetmekten ziyade onu araçsallaştıran bir argümana dayanır. Said-i Nursi (1878-1960) kendi döneminde materyalizme karşı tarikatlar gibi geleneksel dinî gruplarla değil de, modern dinamiklerle cevap verilebileceğini düşünür. Bir başka deyişle modern dünyayla baş edebilmek için yine modern bir strateji ve kavramsal çerçeveyi esas alır. 
Daha çok bir "imanı kurtarma" hareketi olan Nurculuk, modernitenin kendisinden çok onun pozitivist epistemolojisiyle mücadeleye girişir. Bu anlamda Nur hareketi, sosyal ve siyasal alan yerine, modern bilimin verileriyle desteklenen bir İslami bilgi ve zihniyet inşasına yönelir. Said-i Nursi'nin dinî söylemi, bir bakıma, genç nesillerin pozitivist materyalist etkilerden kurtarılması için bilimsel keşifleri önemseyen, modern dinamiklere dayalı bir teolojiyi temsil eder (Yavuz, 2005, s. 205-216).

Söz konusu geleneğin mirasçısı olan Gülenist yapı ise modern değerleri daha çok kamuya açık yüzünde ve özellikle liberal bir temsil için kullanmıştır. Ancak Gülenist cemaatin din söylemi, Nurcu geleneğin pozitivist epistemolojiye karşı geliştirdiği savunmacı eklektik anlayışı devam ettirmekle birlikte, örgütlenme tarzı geleneksel dinî grup ve cemaatlere pek uymaz. Aslında Said-i Nursi'nin pozitivizminde hem geri kalmışlık ve yenilgi karşısında duyulan kolektif kompleks, hem de henüz entelektüel anlamda anti-pozitivist eleştirinin etkili olmaması bir ölçüde mazur görülebilir. Fakat modernitenin temellerine yönelik köklü eleştirilerin yapıldığı bir dönemde bile Gülenist yapının pozitivist paradigmayı sürdürmesi açıklamaya muhtaçtır. Oysa yeni zamanların paradigmatik dönüşümlerinde, bilimsel hakikatlerle dinin hakikatini ifade etmenin, dinî argümanları bilimsel verilerle desteklemenin nispeten bir değeri kalmamıştı. Kanaatimizce, bu pozitivist eğilim iki şekilde açıklanabilir: Birincisi; cemaatin her şeyi araçsallaştıran mantalitesi, ikincisi ise Gülen'in örgütün merkezî figürü ve otoritesi olarak yapılanmanın başında olması, pozitivist ideolojiye özel bir misyon yüklüyordu. Öte yandan, pozitivizme özgü mutlakçı dilin Gülenist yapı açısından bir itaat ve sadakat bağı üretmesi özellikle kayda değer bir işlevdir.

\section{Medrese, Dershane, Işık Evleri; Karşı Kamusallıktan Hegemonyaya}

Nurcu geleneğin ikame ettiği 'dershane’2 olgusu, modern hayatın sorunlarına cevap veremeyen klasik medreselerin alternatifi olarak kabul edilmiştir. Müfredat ve metot bakımından medreselere benzemeyen 'dershane'ler, aynı zamanda sosyal ve maddi fırsatlar temelinde etkileşim imkânı sunan ideolojik, kültürel ve ekonomik ağlar haline gelmiştir. Dershaneler hareketin mensuplarını toplumsal ve kurumsal düzeyde güçlü kılmaya çalışırken, gerçekte daha çok cemaat kimliğinin ikamesi-

2 Buradaki “dershane" kavramı, paralel yapının daha sonraki yıllarda orta ve yükseköğrenim için hazırlık kursları mahiyetinde olan dershaneleriyle karıştırılmamalıdır. Nur cemaatlerinde Risale-i Nurların okunduğu yerlere "Medrese-i Nuriye” denilirken, Gülen ise öğrenci yetiştirmeye odaklandığı ve kendini bu gelenekten ayırmayı hedeflediği için "dershane" kavramını kullanmıştır. Dershaneler, kamuoyunda ise Işık Evleri adıyla tartışılmıştır. 
ni sağlamışlardır. Böylelikle söylemsel düzeyde siyasetten berî bir hareket olarak kendini takdim eden Nurculuk, gerçekte ise dershaneler üzerinden yapisal olarak kurduğu ağ ilişkileri sayesinde yoğun bir şekilde siyasal ilişkilere angaje olmuştur (Yavuz, 2005, s. 226).

Dershaneler, Gülenist yapılanma için de başlangıçta benzer işlevleri taşımıştır. Cemaat bünyesinde "karşı kamusallık"3 denilen paralel yapılaşmayı güçlendiren dershaneler, zamanla toplumsal ve siyasal alanın bütün kurumlarına yayılma ve sızma stratejisiyle merkezî önemini kaybetmiştir. Hareketin faaliyet eksenindeki dershaneler sosyal hayatta, ekonomide, siyasette giderek zayıllayan ağ fonksiyonlarının dışında, paralel dinî söylemin öğretildiği odaklar olarak şekillenmiştir. Öncelikle gayri resmî ideolojik eğitim ve sosyal ilişkilerin inşa ve tahkim edilmesine imkân veren dershaneler, daha çok yapının içsel çekirdek kadroları için özel önem taşımıştır.

Nurcu geleneğin dershaneleri, Gülen cemaatine "Işık Evleri” olarak geçmiş, bir başka deyişle örgütsel yapının ana unsurları "Işık Evleri”nde yetişmiştir. Işık evlerinin temelinde Gülen'in, "her evin bir dershane olması" fikri yatmaktadır (Çobanoğlu, 2012, s. 192). Dershaneler ya da 1şık evlerinden önce örgütlenme dernek ya da vakıf adları altında açılan öğrenci yurtlarıyla başlar ve zaman içerisinde bu yurtların sayısı hızla çoğalır. 1970'li yıllarla birlikte öğrencilerin belli bir sistem içinde eğitildiği ve yönetildiği "Işık Evleri” nin ${ }^{4}$ diğer Nurcu gruplar içindeki adının "medrese" olmasına karşın Gülen kendisini onlardan ayırmak için "dershane” adını kullanmıştır. Nurcuların haftada bir toplanıp sadece Risale-i Nur okudukları medreseden farklı olarak Gülen, kendi dershanelerinde öğrenci yetiştirmeye yönelik bir örgütlenmeyi tercih eder (Veren, 2007, s. 20).

\section{Sosyal Taban ve Eğitimli Genç Kuşakların Endoktrinasyonu}

Risale-i Nur hareketi, dönemin şartları içerisinde, müntesiplerini daha çok okuma yazma bilmeyen kırsal kökenli kesimlerden oluşturmuştur. Ancak Gülenist yapı, diğer Nurcu gruplara ve geleneksel tarikatlara göre, daha çok eğitim gören genç

Hakan Yavuz, "Karşı-Kamusallık" kavramı ile Nur hareketinin gayri resmî dershane ağını yeni karşı-kamunun inşası için basamak olarak kullanmıştır. Karşı-kamusallık laik resmî alanın karşısında yeni dinî bir kamusal alan oluşturmaktadır (bkz. Yavuz, 2005, s. 223, 227-228). Bununla birlikte paralel yap1, kendini toplumsal alanda güçlü bir karşı kamusallıkla sınırlamamış, bürokratik, adli, askerî ve resmî kurumları da ele geçirmeye çalışmıştır.

4 İlk zamanlarda öğrencilerin belli bir disiplin içinde ibadet yapıp Risale-i Nur okudukları evlerde daha sonra Gülen'e biatın da söz konusu olduğu 18 maddelik bir yemin metnine bağlılığın şart koşulduğu ifade edilmiştir (bkz. Veren, 2007, s. 17-18, 127-128). 
kuşaklara yönelmiştir. Başlangıçta faaliyetlerinin odağı olarak eğitimli gençlere yönelen hareket, zamanla, şehirli orta sınıflar (Çobanoğlu, 2012, s. 329), iş adamları, esnaf ve zanaatkârlar ile resmî kurumları da kuşatarak sosyal tabanını ve kitlesini genişletmeyi hedeflemiştir. Sosyal profili değişen hareket, bu süreçte geleneksel dinî kodları da dönüştürerek içeride ve dışarıda farklılaşan kavram ve değerleri kullanan paralel bir yapıya dönüşür. Kamusal alanda hoşgörülü ve uzlaşmacı dili kullanarak sivil sosyal bir oluşum imajı üreten hareket, içyapısında ise bir imamlar hiyerarşisi ve abi-abla endoktrinasyonuyla kapalı bir örgütlenmeye gider. Bu bakımdan informel dershane ağları, "tedbir" temelli bir motivasyonla, toplumsal alanda "takiyye" stratejisine denk geliyordu.

\section{Siyaset Karşıtlığından Tahakkümcü Siyasete Geçiş}

İlk dönemlerinde siyasete mesafeli duran Nurculuğun, süreç içinde siyasi ilgi ve ilişkilere angaje haline gelmesi tartışma konusu olmuştur. Siyasal eğilimlerin çok partili hayata geçişle birlikte ortaya çıktığı ve organize olduğu söylenebilir. Ancak siyasetle ilişkinin konjonktüre göre açı̆̆a çıkan bir ilgiden çok, Nur geleneğinde mündemiç bir özellik olduğu anlaşılmaktadır. Nitekim bu eğilimi Nursi'nin hayat hikâyesinde de izlemek mümkün olup, onun II. Abdülhamit'e karşı Jön Türkler'le iş birliğine gitmesi, siyasi tavırlar konusundaki naif duruşunu gösterir. Bununla birlikte, Cumhuriyet sonrası dönemde siyasete karşı ihtiyatlı ve mesafeli söylemin öne çıkarılması, Nur geleneğinin sosyo-kültürel alana açılma ve gelişme eğiliminden kaynaklanmıştır.

Said-i Nursi, Cumhuriyet sonrası dönemde, dinî hedefleri olan bir parti kurma, devlet mekanizmalarını ele geçirme ve yukarıdan aşağıya bir değişim gerçekleştirme gibi bir hedeften uzak durmaya çalıştı. Bununla birlikte, 1946 seçimlerinde açıkça Demokrat Parti'yi desteklemesi, oy kullanmak için seçim bölgesine gitmesi gibi faaliyetlerinin onun siyasetten uzak durma söylemiyle uyuşmayan pratikleri olduğu açıktır. Nurculuğun kamusal alanda yer açma eğilimine bağlı olarak siyasetle kurulan pragmatik ilişkiler sebebiyle çoğu zaman "güvenilmez" ve "gayri samimi” olarak değerlendirilmelerine yol açmıştır. Gülenist yapının siyasetle ilişkisi ise Gülen'in biyografisinde belli dönemlere tekabül eden süreçlerle bağıntılı açıklanabilir. Hareketin siyasallaşma süreci, örgütsel dönüşümle ilgili kısımda ele alınacaktır. Ancak genel bir bakışla, Nurcu geleneğin köklerinde yer alan "siyasete söylemde uzak, fiiliyatta iç içelik durumu"nun, siyaset dışı tahakkümcü bir strateji izleyen paralel yapılanmanın temel kodunu oluşturduğunu belirtmeliyiz. 


\section{Gülenist Yapının Teolojik Söylemi}

Gülen'in vaazlarında ve yazılarında öne çıkan teolojik söylemin ana unsurları, Nurculuğun din söyleminden ve metinlerinden mülhemdir. Başlangıçta büyük ölçüde Risale-i Nurları eksene alan hareketin din dili, Gülen'in zamanla külliyat haline dönüşen vaaz ve kitaplaryyla müstakil bir karakter arz etmiştir. Söz konusu kökensel bağllık nedeniyle grubun zaman zaman "neo-nurcu" bir akım olarak kodlandığ görülse de, yapının 1990’lı yıllarla birlikte artık Nurculuktan bağımsızlaştığı, zihnî ve kurumsal pratiklerle kendini ana akım haline getirmeye başladığı söylenebilir. S. Nursi ve Risalelerin Gülenist yapı tarafından araçsallaştırıldığı, hatta kendi metinlerini ve cemaatini inşa edene kadar bilinen metinsel birikimden yararlandığ 1 anlaşlmaktadır.

Gülenist örgütün geçirdiği ideolojik değişim, başlangıçtaki din söylemine göz atıldığında açık bir şekilde görülmektedir. Bu bağlamda dikkati çeken ilk unsur, Gülen'in ilk döneminde "millî unsurlara" vurgu yaparak, devletçi ve milliyetçi bir söylemi kullanma eğilimi olmuştur. Hatta bu çerçevede, İslam'in savunulması ve yorumlanmasında Türklerin oynadığı olumlu rol ve hoşgörü karakteri bilinçli bir şekilde öne çıkarılmış ve bu din anlayışı "Türk İslam'ı" olarak kodlanmıştır (Çobanoğlu, 2012, s. 253). Yapının iptidai milliyetçi teamüllerinin, bir bakıma kendini diğer dinî gruplardan ayırt etme, Anadolu'daki milliyetçi damardan beslenme gibi oportünist amaçlarla ilgili olduğu düşünülebilir. Ancak bu taktiğin Türkiye'deki geniş sağ muhafazakâr kesimleri içine alacak bir şemsiye stratejisi olduğu, daha sonraki süreçlerde liberal kesimler için de benzer başka kavramları ve pratikleri sahaya sürmesinden anlaşılmaktadır.

Gülenist yapının din söyleminde, Nur geleneğiyle irtibatlandırılabilecek bir eğilim olarak Siyasal İslam'a ya da İslami siyasete yönelik bir tepki ve muhalefet vardır. Bu bakımdan, İslam dünyasında başta İran olmak üzere kimi Orta Doğu ülkelerinde ortaya çımış İslami hareketlere karşı kendini İslam dünyasında barışçl dinî eğilimin temsilcisi ilan etmeye çalı̧̧ıştır. Hareket, Batılı küresel bazı jeopolitik güçlerce çizilen "Ilımlı İslam" projelerinde kendisine rol biçerek bu çerçevede, başta eğitim alanında olmak üzere, diyalog ve iş birliği gibi süreçlerde görev üstlenmiştir. Bu çerçevede Sünni ana akımın temsilcisi iddiasıyla Anadolu Türk Müslümanlığını Arap ve İran kaynaklı siyasi İslam’a karşı öne çıkaran hareket, paradoksal biçimde dinlerarası diyalog ve işbirliği gibi geleneksel Sünni kodları tahrip edecek bir yola girmiştir.

Gülenist yapının bunun dışında toplumsal dinî hayat bakımından geniş bir izleyici kitlesine hitap etmesinin bazı nedenleri bulunmaktadır. Hareketin ideolojik alt yapısında, "dünyacı bir dindarlık" dili kullanılmıştır. Aktif dünyacı dindarlık eği- 
limi, modern hayata katılmayı talep eden ve bu yolda bazı hümanist değerleri kolaylıkla içselleştiren bir yönelimdir. Toplumsal stratejisinde geniş kurumsal alanlara yayılmayı hedefleyen hareket, böylelikle kendi müntesipleri için motive edici bir yol haritası çiziyordu. Diğer yandan, artan toplumsal hegemonyaya paralel olarak, sosyal ve siyasal zeminde meşruiyet için geleneksel dinî literatürle ilişkisi olmayan kimi bazı liberal kavramlar sahiplenilmiştir. Bu süreçte, grubun artık kendisini klasik bir dinî cemaat gibi değil de sivil sosyal bir hareket gibi tanımlaması, esasta Sünni kodlardan uzaklaşmayı kamufle edici nitelik taşır.

Hareketin esas çelişkisi, her türlü İslami siyasete ve sosyal hareket olarak İslamcı gruplara karşı olduğunu deklare etmesine rağmen, pratikte örtülü siyasi ilişkilere ve siyaset dışı operasyonlara uygun bir yol izlemesinde ortaya çıkmıştır. Gülenist yapı, siyasallaşmış din yorumlarına muhalefet ederken, hareketin menfaatleri adına, İslami geleneğe uygun düşmeyen her türlü ittifaka açık bir taktik peşinde olmuştur. Bu çerçevede, özellikle 28 Şubat döneminde Milli Görüş geleneğine ve Siyasal İslamcılığa alternatif uyumlu-1lımlı bir din anlayışını temsil ettikleri iddiasıyla içeride demokrasi dışı zihniyete, dışarıda ise İslamofobik güçlere yakın mesajlar vermiştir.

Gülenist yapının din söyleminde belki de en önemli tema, İslami gelenekte karşılığı bulunan "ahir zaman beklentileri" ve "mehdilik" meselesi olmuştur. Nitekim mehdilik konusu Risale-i Nur hareketi açısından da önem atfedilen bir mevzu olup, Said-i Nursi bu bakımdan zaman zaman müntesiplerinin kafasını karıştıracak cifr hesaplarıyla uğraşmış, genelde ise "şahs-1 manevi” olarak yorumladığı mehdinin Risalelerde ve takipçilerinde somutlaştığına inanmıştır. Nitekim kişisel hayatını böyle bir inanca zemin hazırlayacak şekilde hikâyeleştiren Gülen de mehdici yorumları kullanarak hareketin özellikle iç halkalarına bağlılık için zemin hazırlamıştır.

Hareketin kullandığı kendine özgü dinî terminolojinin, daha çok grubun faaliyetleri ve örgütlenmesi içinde özel işlevlerle farklılaştığı görülmektedir. Örneğin bu çerçevede öne çıkan "hizmet, himmet ve adanmışlık"5 gibi kavramlar, hem grubun tanımına hem de faaliyetlerin içeriğine işaret edecek şekilde özelleşmiştir. Öte yandan, bu kavramların grup tarafından operasyonel biçimde kendilerinin Türkiye'de İslami modernleşmenin ve gelişmenin itici gücü olarak lanse edilmesinde kullanılması da dikkat çekmiştir. Ancak bu yaklaşım, daha çok sermaye çevrelerinin ve yeni orta sınıfların hoşuna gidecek şekilde, gruba ait bir misyon olarak piyasaya sürülmüştür.

5 Bu metin boyunca Gülenist yapıyı tanımlamada zaman zaman "Gülenist cemaat, Gülenist grup veya Paralel yapı" gibi terimleri kullanmayı tercih ediyoruz. "Gülenist cemaat” terimi ise dinî bir cemaat değil, dinî temaları kullanan ezoterik, örgütsel yapı anlamında kullanılmıştır. 
Gülen'in din söylemi, örgütsel stratejisine uygun biçimde, sürekli manevralarla yön değiştiren bir karakter sergilemiştir. Örneğin doksanlı yıllarda Türkiye'nin "1lımlı, mütevazı, duygusal ve ağlayan hocaefendisi" olarak imajı parlatılan Gülen, kamusal alanda çok farklı kesimleri şemsiyesi altına toplayacak liberal ve hoşgörülü İslam söylemiyle sosyal sermayesini artırmış, toplumsal siyasi güçlerle ilişkilerini geliştirmiştir. Nitekim bu süreçte artan gücüne ve prestijine paralel olarak, başta kendi güdümündeki medya etkisiyle, farklılıkları uzlaştırıcı ve kapsayıcı liberal bir terminoloji piyasaya sürülmüştür. Operasyonel ve oportünist değişimin yanı sıra, illegal yapılanmasında kurumsal ve bürokratik bir güç temerküzüne koyulan hareket, 1lımlı, sivil bir sosyal hareket olarak kendini lanse ederken dinî cemaat formundan da giderek uzaklaşmıştır (Yavuz, 2004, s. 81). Gülenist Paralel yap1, dinî grup veya cemaat kategorisinden tamamen uzaklaşmasına rağmen, kamuoyu ve iç halkalarındaki müntesipler bu farklılaşmayı çok önemsememiş, dönüşümü dikkate almamıştır. Diğer yandan hareketin sosyal, siyasal ve ekonomik sermayesinin giderek genişlemesi, onlar aracılığıyla din söyleminin sekülerleşmesini de temellendirmiştir.

Gülenist yapının din söylemindeki savrulma ve inhirafların ortaya çıkmasında, 28 Şubat 1997 Postmodern Darbe'nin etkisi dikkat çekicidir. 28 Şubat döneminden sonra, grubun söylemleri hızla küreselci uluslararası bir dile dönüşür. Bu dönüşümde, grubun artık giderek hasılasını toplamaya başladığı küresel ağlar ve güçlerle iş birliğinin yansımaları vardır. 28 Şubat döneminde Gülen'in İslami hassasiyetleri, ilke ve pratikleri önemsizleştirici açıllamaları takiyye siyasetine uygun biçimde örneğin "başörtülerini açmaları, sosyal ilişkilerde dindarlıklarını gizlemeleri” gibi tavsiye ve yönlendirmeleri, diğer İslami gruplar ve cemaatler tarafından şiddetle eleştirilir (Acar, 2016, s. 92-93).

Gülen'in oportünist manevraları ile din anlayışında ortaya çıkan savrulma, Said-i Nursi ile Gülen arasında yapılan karşılaştırmalarla örneklenmiştir. Bu çerçevede, Said-i Nursi'nin söyleminde 'dünya' değersizleşirken, Gülen'in düşüncesi 'bu dünyacı'dır ve dünyevi tahakküme meyillidir. S. Nursi aşırı sekülerleşme dalgası karşısında imanın yeniden güçlendirilmesine yönelmişken, Gülen sosyal, ekonomik, siyasal ve bürokratik alanlara yayılmaya daha fazla önem atfeder. S. Nursi, materyalizmin etkili olduğu bir çağda gençlerin imanını kurtarmak ve yeniden inşa etmek peşindedir; Gülen'de ise gruba mensubiyet duygusuyla birlikte aksiyon ve sosyo-ekonomik yapılara hâkim olma düşüncesi baskındır. Gülenist yapının eylemciliği, kendisini Nur geleneğine dayandırmakla birlikte, daha çok toplumu ve devleti dönüştürmeyi amaçlayan bir çizgiye dayanır. S. Nursi kişisel dönüşüme odaklanmışken, Gülen ekonomik ve siyasal şartlardan da yararlanarak toplumsal hege- 
monyayı ele geçirmeye çalıştı (Yavuz, 2005, s. 255; 2004, s. 59). Gülenist yapı bir yandan kamusal alanlara yayılma ve kritik kurumlara egemen olma, bir yandan da kendi nüfuz alanında sekülerleşmeyi teşvik etmiştir. Bu karşılaştırmalarla birlikte S. Nursi'ye atfedilen özelliklerin her dönem için geçerli olmadığını, kritik zamanlarda Nursi'nin de bazı siyasi tercih ve eylemlere giriştiğini akılda tutmak gerekiyor.

Gülenist yapıyı, süreç içindeki değişimine istinaden, Neo-Nurcu bir grup olarak tanımlama girişimleri olsa da, neticede hareketin Nurculukla ilişkisi sorguya açıktır. Cemaat içinde Risale-i Nur'a iltisak devam etmekle birlikte, Risaleler zamanla eksen ve yönlendirici metin olmaktan çıkmıştır. Hatta bu bakımdan ikinci dönemin mensuplarında "risale okumayanlara" rastlamak olağan karşılanmıştır. Gülen, legal ve illegal bütün imkânları seferber ederek, küresel bir güç olma çabasıyla farklılaşma yolunu seçer. İşaret edilen bütün bu farklılıklardan dolayı, Gülenist yapıyı Nurculuğun bir devamı anlamında Neo-Nurcu olarak tanımlamak olgusal duruma uygun düşmeyecektir (Çakır, 2014, s. 183-184). Dolayısıyla hareketi Neo-Nurcu değil ama artık geleneksel Nurculuktan uzaklaşmış ve farklılaşmış anlamında "Post-Nurcu" kavramıla kritik etmek mümkündür.

Gülenist yapının başlangıçta içeriye yönelik millî ve tarihî vurguları öne çıkarılmış hoşgörülü Türkiye Müslümanlığı ile küresel iş birliği sürecinde dışarıya ve liberallere yönelik insan hakları ve çoğulcu postmodern temalarla karıştırılmış "Çağdaş İslam" projeleri, bir bakıma nabza göre şerbet taktiğine tekabül etmektedir. Hatta sivil toplum alanında artan gücüne paralel olarak sivilleşme, demokratikleşme, diyalog ve hoşgörü gibi kavramları, diğer İslami grup ve hareketlerden ziyade gayri İslami grup ve oluşumlarla ilişkilerde kullanması hareketi güvenilmez ilişkileri ve niyetleri bağlamında tartışmaya açıyordu. Yavuz'a göre, Gülenist yapı temelde cemaat içinde disiplin ilkesini işletirken, özellikle gayrimüslimlerle ilişkide diyalog ilkesini öne çıkarmıştır (Yavuz, 2005, s. 268, 273).

Cemaatin din söylemindeki diyalog vurgusu ve özellikle dinlerarası diyalog faaliyetlerinin Türkiye'deki referansı olması, Yapıyı öteki dinler ve gruplarla ilişkilerin bir zemini durumuna getirmiştir. Sosyal örgütlenme kısmında ele aldığımız bu konu, cemaatin din tasavvurunda değişimin izlenebileceği önemli başlıklardan birini oluşturur. Genel yaklaşımlarında oldukça gelenekçi bir tavır takınan ve dinî düşüncede yenilik gibi kavramlara soğuk duran Gülen'in din anlayışı, özellikle dinlerarası diyalog konusunda da Ehli Sünnet dışı bir çizgiye kaymıştır. Gülen'in 1998'de Papa II. John Paul ile Vatikan'da görüşmesini müteakiben "dinlerarası diyalog”u bir proje olarak hayata geçirmeye yönelmesi, ABD eksenli bir küresel siyasetin talepleri doğrultusunda İslam'ı 1lımlı yüzünü temsil rolünü üstlenmesi genelde dikkatten kaçmış (Öztürk, 2013) ya da görmezden gelinmiştir. Gülen'in din söylemindeki di- 
yalogcu tavır ile radikalizm karşıtlığı birbiriyle uyumludur. Bu bağlamda, Papa'nın yanı sıra, İstanbul'da Ortodoks Fener Patrikhanesi ve Ortodoks Kilisesi, Hiristiyan ve Musevi liderleriyle de görüşmeyi ihmal etmemiştir. Hareketteki dinî söylem diyalog temelli girişimler ve kavramlar üzerinden "küresel bir misyona" dönüşümü gösterirken, bu sürecin hangi amaca hizmet ettiği konusu hep muamma olarak kalmıştır. Gülenist cemaatin din söylemindeki oportünizm, eklektik karakteriyle gizlenmeye çalışılsa da içeriye ve dişarıya yönelik değişen tutum ve tavır alışları içermesi (takiyye) tartışmalardan ve eleştirilerden hâlî kalmamıştır. Ancak hareketin kamusal alanda ve kültürel kurumlarda (medya, siyaset, sivil toplum) elde ettiği devasa gücü ve nüfuzu, yapılan bu eleştirileri dikkatlerden uzak tutuyordu.

Gülen, doksanlı yıllar boyunca hareketin artan medya gücüyle dışa yönelik diyalogcu, kuşatıcı liberal bir söylemle merkeze oynuyordu. Onun temsilciliğinde hareketin kazandığı yeni pozisyon, bir yandan içeride farklı kesimlerin sempatisini kendine çekerken, diğer yandan dışarıda küresel hegemonyanın hesaplarına uygun bir diyalog söyleminin taşeronluğunu üstleniyordu. Gülenist yapı "dünyanın her yerinde dinlerarası diyalog" temasıyla kendini meşrulaştırıyor, böylelikle ya dinlerarası örgütler, dernekler ve topluluklar kurarak ya da din adamlarıyla yakın temas içinde hareket ediyordu (Yılmaz, 2004, s. 279, 285-286).

Gülenist yapının diyalogcu dilinde küreselci postmodern söylemin izlerini görmek şaşırtıcı değildir. Bilindiği üzere, postmodern söylemde hakikati tekelinde tutan bir dine yer yoktur. Postmodernizm, insanların kendi dinlerinin yegâne hakikat olduğuna ilişkin inançlarını sarstı ve bütün dinlerin aynı değerde olduğu kabulünü yaygınlaştırdı (Wenzel, 2012, s. 285-7). Yeni çoğulcu, liberal, küresel din piyasasında yer almak isteyen yeni dinî gruplar ve hareketler, daha çok diyalogcu söylem zemininde yürümeyi tercih ederler. Mehdici-mesiyanik karakterli Gülenist yapının da uluslararası bir güç haline gelirken, inançlar ve pratikler bağlamında kendine zemin açmak için postmodern söyleme sarılması bu anlamda özel bir stratejiye işaret eder.

Hareketin dinlerarası diyalog konusundaki görüşleri ve bu çerçevede geliştirdiği uluslararası faaliyetleri, özellikle diğer cemaatler ve İslami gruplar tarafından en çok eleştirilen husus olmuştur. Gülen, diyalog çalışmalarıyla Batılı dinî kurumlarla, özellikle de Vatikan'la, yakın ilişkiler kurmaya çalışmıştır. Dinlerarası diyalog meselesine her ne kadar "farklı dinleri birleştirme veya bir potada eritip yeni bir din üretme teşebbüsü değildir" denilse de, diyalog projesinin Kilise tarafında "Kurtuluşun tabii yolu Kilise'dir, diyalog faaliyetleri bütün insanları Kilise'ye döndürme amaçlı misyonun bir parçasıdır." açıklamasıyla, diyalogun aslında bir Vatikan projesi olduğu açıktır. Nitekim Gülen'in 9 Şubat 1998'de Papa'ya ilettiği mektupta yer alan ve diyaloğu bir misyon olarak üstlenen ifadeleri bu konu için bir delil duru- 
mundadır. Cemaatin uluslararası diyalog faaliyetlerinde $\mathrm{Hz}$. Muhammedsiz bir kelime-i tevhid önermesi bu özel yaklaşımının ipuçlarını taşır. Öte yandan, hareketin aslında amaçları ve organizasyonu çok net olmayan uluslararası nitelikli "Diyalog Projesi”nde adeta "Hıristiyanlık lehine gönüllü bir hizmet sağladığı”na ilişkin eleştiriler (Öztürk, 2014a), cemaat tarafından da reddedilmeyen bir kabul olmuştur.

\section{Gülen Cemaatinin Paralel Yapıya Dönüşümü}

Ekonomik ve sosyal gelişmelerle birlikte yeni orta sınıflar için fırsat alanlarının genişlediği seksenli yıllarda Gülenist yapı, muhafazakâr bir cemaatten, devasa bir karş1-kamusallığa ve son aşamada ise küresel ölçekli bir örgütsel yapıya dönüştü. Bu süreçte, paralel yapının dört aşamalı bir evreden geçtiğini söylemek mümkündür. Birinci evre; "oluşum dönemi" diyebileceğimiz 1966-83 arasıdır, ikinci aşama; "kamusal alana yayılma” olarak tanımlanan 1983-97 arası, üçüncü evre; 1997 sonrasından 2010'lu ylllara kadar uzanır (Yavuz, 2005, s. 242). Bütün bu evreler kendi içinde tarihsel eşiklerle ayrışsa da cemaatin devlet kurumlarına sızma stratejisi her dönemde devam etmiştir. Paralel yapının dördüncü dönemi ise 2010 sonrasında ve özellikle 17 Aralık 2013 Darbe Girişimi’yle birlikte başlayan ve günümüze kadar süren dönemdir. Artık bu aşamayla birlikte Gülenist yapı, kamuoyunda ve kamusal alanda devşirdiği kazanımları korumaya yönelik taktiksel değişime gider. Esasen illegal faaliyetlerinin, kritik devlet kurumlarına sızarak güç toplamanın iyice açığa çıkması nedeniyle meşru siyasi iktidarı her türlü araçla yıpratmaya ve yıkmaya yönelmiştir. Bu aşamada medyasını ve siyaset dışı bütün araçları kullanan yapı, hem nüfuz ettiği yargısal süreçler hem de aşırı siyasallaşma nedeniyle sosyal ve kültürel sermayesinde ciddi bir kayıp yaşamış, çatışmacı bir dile evrilerek, küresel güçlerle iş birliği içinde, içeride ve dışarıda meşru Türkiye Cumhuriyeti hükûmetini ve özellikle Başbakanlığı ve Cumhurbaşkanlığı döneminde hem şahsında hem de makamında Recep Tayyip Erdoğan'ı yıpratmaya ve yıkmaya yönelik birtakım operasyonlara girişmiştir. ${ }^{6}$

Gülenist yapının birinci döneminde (1966-83), siyasi alana çıkmadan, dinsel örgütlenmenin temelleri atılır. Işık Evleri ve dershaneler süreci olarak adlandırılan bu aşamada paralel yapı içe dönük bir strateji izler. Bu bakımdan muhafazakâr-mil-

6 Bu aşamada, F. Gülen dinî bir lider ve cemaati de dinî bir gruptan ziyade bürokraside, yargı ve emniyet gibi devletin kurumlarında örgütlenerek güç devşirmeye çalışan ve "paralel yapı" kavramıla tanımlanan bir unsur olarak hukuki süreçlerin konusu olmaya başlamıştır. Öte yandan, bu tanımın çok kısa bir süre içerisinde kamuoyunda genelleşerek resmî adlandırma vasfını aştığı ve geniş kabul gördüğü anlaşılmıştır. 
liyetçi bir söylemi dillendirirken, sosyal alanda dershaneler ve '1şık evleri' vasıtasıyla informel ağ sistemini genişletme amacını güder. Gülenist yapının ikinci dönemi (1983-97), kamusal ve sivil alanda yaygınlaşarak meşruluk zeminini genişletmeye çalıştığı dönemdir. Bu aşamada Özallı yılların getirdiği siyasi, sosyal ve ekonomik firsat alanlarından yararlanan Yapı, "altın nesil” yaratma vizyonunu uygulamaya koyar. Neo-liberal politikaların öne çıktığı bu dönemde Gülen, liberalizmle uyumlu bir dindarlığı temsile yönelmiş, Millî İslam fikrini güncelleyerek devletçi bir siyaset izlemiştir. Yine bu evrede hareket, siyasal iktidarlarla uyumlu pragmatik ilişkilerin neticesi olarak yerel vakıflar ve dernekler aracılığıla en etkili gruplardan biri haline gelir. Nitekim eğitim, kültür, ekonomi ve medya alanındaki faaliyetlerle kamusal alanda kurumlaşır, resmî kurumlarla yakın bağlar kurar. Bu süreçte cemaat emniyet, ordu ve yargı gibi kritik kurumlara sızarak hegemonik bir güç olma yolunda ilerledi. Yapının formel ve informel kurumlar ağı, Türkiye'nin dişında Orta Asya, Balkanlar ve Avrupa'da da yayılmaya başladı. İkinci dönemde ekonomik ve sosyal sermayesini artıran örgüt, özellikle eğitim alanında uluslararası bir ağ haline geldi. Bu süreçte, Türkiye'de ve dünyanın pek çok ülkesinde her düzeyde okullar açtı ve böylelikle kendini uluslararası bir eğitim hareketi misyonuyla tanımlamaya başladı. Bu dönemde Gülen, 1lımlı ve liberal yorumlar yaparak, toplumun farklı kesimlerine uzlaşmacı ve diyalogcu bir dille yaklaşan "Hocaefendi" olarak şöhret buldu ve meşruiyet kazandı. Dindar zümrelerin sekülerleşmesini hızlandıran (Yavuz, 2004, s. 78; 2005, s. 245-249) bu süreçte hareketin, Protestanlaştırıcı bir proje olduğu zaman zaman dile getirilmesine rağmen, bu konu üzerinde çok durulmadı ya da bazılarınca toplumsal gelişme açısından olumlu bir etken olarak kabul edildi.

Küreselleşme olgusunun yaygınlaşmaya başladığı ikinci aşamada Gülenci yapı, kendini "irşattan temsile geçiş"le tanımlıyor, içeride ise farklı etnik, dinî, kültürel unsurları kendinde toplayan bir merkez gibi ideolojik sermayeyi uhdesine almaya çalışıyordu. Bu dönemde farklı görüşten ve inançtan kişileri dâhil etme girişimi, Gazeteciler ve Yazarlar Vakfı (GYV) aracılığıyla gerçekleştirildi. Bununla birlikte, sivil ve sosyal alandaki etkili örgütlenme ağı dönemin resmî siyaseti tarafından şüphe ve endişeyle karşılandı (Yavuz, 2004, s. 82). Gülenci yapılanma, bu evrede siyasetle derin ilişkiler geliştirmek için bütün fırsatları kullandı. Nitekim 1980 sonrasında Gülen, sırasıyla Turgut Özal, Tansu Çiller ve Bülent Ecevit'le yakın ilişkiler kurarak kendisi ve cemaati için avantajlar sağladı (Çakır \& Sakallı, 2014, s. 29).

İkinci dönem boyunca sağladığı siyasi ve ekonomik avantajlar sayesinde, cemaat orta ve üst sosyal gruplar ile statü arayışındakilere giderek çekici hale gelmiştir. Nitekim yüksek hareketliliğe sahip ağlar arayan ve seçkinci yönelime sahip işadamları, öğretmenler, akademisyenler, gazeteciler, diğer meslek grupları ve üniversite 
öğrencileri grubun bu dönemdeki sosyal tabanını oluşturdular. Bu dönemde hareketin sosyal sermayesi o kadar yüksek ve cazip hale geldi ki, bu durum katılımın da devasa boyutlara ulaşmasına sebep oldu (Yavuz, 2004, s. 77).

Gülenist hareket, 1980-2000 arasında genellikle ikili bir yapı göstermiştir. Hareket; "1şık evlerinde" ve yurtlarda erkek öğrenciler için "abi”, kız öğrenciler ve kadınlar için de "abla" statülü eğitici ve örgütleyici kişiler vasıtasıyla kendi kadrolarını oluşturdu. Birinci halkayı oluşturan bu kadrolar, hareketin gizli ve asli unsurları olarak faaliyet gösterdi. İkinci halka ise özellikle iş adamları ve orta ölçekte ekonomik güce sahip kişilerden oluşmaktayd. Örgütün organizasyonel yapısı; başlarında Gülen'in bulunduğu bir istişare heyeti, bunlara bağlı olarak ülke, il, ilçe düzeyinde imamlar ve okul sorumlularından müteşekkildi (Şentürk, 2011, s. 264-265). Ancak bu imamlar, abiler, ablalar hiyerarşisi, örgütü modern bir kült olarak dinî kavramları çarpıtan gizli masonik bir teşkilata dönüştürürken, sosyal sermayesindeki yükselişten dolayı İslam itikat sisteminden uzaklaşması kamuoyunca pek fark edilmiyordu.

Gülenist hareketin üçüncü dönemi (1997-2001), "postmodern darbe" de denilen 28 Şubat 1997'den sonra başlar. Gülen'in yurt dışına çıktığı bu dönemde, paralel yapının artık giderek küreselci bir söylemi sahiplendiği görülür. ABD'deki Gülen, Türkiye'deki milliyetçi-devletçi retoriğin yerine "dinlerarası diyalog", "coğrafi vatan" kavramı yerine birtakım dinî değerler/sembollerle ifade edilen genişlemiş bir vatan ve insan hakları gibi kavramlar etrafında yeni bir anlayış geliştirmiştir. Üçüncü dönemde, küreselleşme bağlamına uygun bir din anlayışının yerleştirilmeye çalışıldığı anlaşılmaktadır (Öztürk, 2013). Gülenist yapı, bu süreçle birlikte Türkiye'de kendini yargısal ve siyasal bakımdan sıkışmış gördüğü anda, küresel güçlerle iş birliğini daha fazla öne çıkarmış, kimi uluslararası projelerde aktif rol alarak Türkiye'yi dışarıdan kontrol etmeyi tercih etmiştir.

Gülen, kamuoyunda kendini demokrasi yanlısı 1lımlı bir lider olarak tanıtmas1na karşın, 28 Şubat döneminde askerî vesayetin Refah Partisi'ne ve İslami gruplara yaptığı antidemokratik baskıcı uygulamalar karşısında darbeci zihniyetin yanında yer aldı. Bu tutum, hareketin gerçekte demokrasi kaygısına sahip olmadığını, aksine, her dönemde güç ve iktidar sahipleriyle konjonktürel ilişkiler kurarak kendi yapısını korumayı amaçladığını gösteriyordu (Çakır \& Sakallı, 2014, s. 31). 1999'da Gülen cemaatinin devletin laik yapısına yönelik bir tehdit olduğuna ilişkin yayınların artması üzerine Gülen hakkında yasal takibat başlatıldı, ancak mahkeme tutuklama talebini reddetti. Bununla birlikte suçlamalar durmadı ve dönemin cumhuriyet savcısı, "devletin laik yapısını yıkmak üzere kurulan Gülen örgütünün, 1989 yılından bu yana ülkeyi meşveret heyetleri, bölge, şehir, mahalle ve yurt liderleri dâhil olmak üzere legal ve illegal ağlarla ördügünü” deklare etti. Ancak Gülen, bu 
süreçte ABD'ye kaçtı ve bir daha geri dönmedi. Öte yandan, paralel yapının kritik devlet kurumlarına sızma stratejisi açığa çıktıkça Gülen'in liberal din yorumlarının gerçek tavirlardan ziyade "takiyye" olduğuna ilişkin kanaatler de güçlendi (Yavuz, 2005, s. 275-276; 2004, s. 84-85).

Gülenist yapı, özellikle 2000'li yıllarda, klasik Nurcu söylemlerin pasif eylemci yaklaşımından hızla uzaklaşmaya ve toplumsal siyasette özellikle siyaset dışı araçlar üzerinden etkin olmaya başlamıştır. Bu süreçte örgüt, iktidarlara yönelik stratejisini AK Parti iktidarına da uygulayarak çok sıkı ilişkiler geliştirmeyi hedeflemiştir. Ancak kritik kurumlarda bir ağ gibi yayılan paralel yapı, bu dönemde iktidara yakınlık kurarak güvenlik sağlama stratejisini aşmış, siyasal ve sosyo-ekonomik sermayesini devasa bir şekilde genişletmiş, kamusal ve kurumsal alanda hegemonik bir güç olmuştur. Yargıda, emniyette ve medyada oluşturduğu ağ ilişkisi sayesinde "Ergenekon Davası" olarak bilinen ve bazı asker-sivil-akademisyen-gazetecilerden oluşan ve devlet yönetimini ele geçirmeye, sivil iktidara karşı darbe yapmaya çalıştıkları ve bu amaçla örgütlendikleri iddia edilen oluşuma karşı süreci maniple etti. 2010 yılında yapılan anayasa referandumunda açıkça "evet” propagandası yapan Gülenist yap1, böylelikle siyasi hayatta etkinliğini giderek artırdı (Şentürk, 2011, s. 267).

Şartlara göre dil ve söylem değiştiren Gülen, vaizliğinin ilk yıllarında daha çok akla hitap eder görünürken seksenlerde bir popüler vaiz gibi ağlama ve gözyaşları içinde, cezbeye getiren batıni teşbihler, rüyalarla renklendirilmiş coşkulu vaazlarla piyasa buldu. Doksanlarda ise vaazlarında cezbeli unsurlar ortadan kaybolmuş, onun yerine felsefi-mistik vecizeler ortaya çıkmıştır. Bu dönemde gaipten haberler veren, ilahi güçlerle doğrudan temas halinde onların desteği ile maddi dünyayı etkilemeye yönelik hezeyanlar oldukça revaçtadır (Akçay, 2014). Gülen'in söz konusu değişimle Nur geleneğindeki mehdici-mesiyanik kodları harekete geçirdiği anlaşılmaktadır. Ancak kullandığı dil ve uyguladığı strateji bakımından hareket giderek modern bir kült formuna yaklaşır. Gülen'in bütün hareket ve faaliyetlerinde takip ettiği strateji ise "güç eksenli" olup, bu bakımdan hegemonik bir güç olma yolunda dilini ve değerlerini değiştirmekte tereddüt etmez.

Gülenist yapının sosyal örgütlenme temeli, dershaneler gibi informel yapılara dayanır. Dershaneler, Nurcu gelenekte dinî sohbet dışında sosyal, siyasi ve ekonomik ağ ilişkilerine de imkân veren yerler olarak işlev taşımıştır. Bu bakımdan dershaneler, sadece eğitimli genç kuşaklar için değil, gelişmekte olan kentlerde esnaf, zanaatkâr, tüccar ve serbest meslek sahipleri için de bir cazibe odağı olmuştur. Nitekim bu işlevleri ve özellikleri sayesinde dershaneler, örgütsel dinî yapıların kamusal alanda genişlemesine, daha doğrusu paralel yapilar olarak güçlenmesine fırsat vermiştir. Hareketin dershaneleri, kamuoyunda kapalı devre, gizli ve örgütsel ilişkilerin hüküm sürdüğü 'Işık Evleri' olarak bilinegelmiştir. İşleyişinde üstte- 
kini alttakilerin tanımadığı bir hiyerarşinin yönettiği öğrenci evleri ve dershaneler, dışarıdan bakıldığında Nursi ve Gülen'in eserlerinin okunduğu yerler olarak alg1lanmış, bu sebeple muhafazakâr ve dindar ebeveynler, okumak için gönderdikleri çocuklarını söz konusu evlerde yaşamaya teşvik etmiştir (Yavuz, 2005, s. 226-228; 2004, s. 72-73). Bu dönemde cemaat evleri ve yurtlara, daha çok, barınma sorunu yaşayan öğrencilerin yerleştirilmesi söz konusudur. Bir başka deyişle kız ve erkek yurtları, taşradan çocuklarını okumaya gönderen aileler için, cemaate katılmaktan ziyade, çocukların kalabileceği güvenli mekânlar olarak tercih edilmeye başlanmıştır. Ancak süreç içerisinde hazırlık kursları ve dershaneleri de ağına alan paralel yap1, bu mekânlarda izlediği stratejik programlarla, öğrencileri üniversitelerin d1şında ayrıca polisliğe, askeriyeye ya da yargıya yerleştirmeye yönelik bir faaliyete odaklanmıştır. Gülenist grup, böylelikle, bireysel değişimi esas alan Nur geleneğinden köklü bir şekilde inhiraf etmiş, ancak sosyokültürel değişimden ziyade sosyopolitik bir değişime yönelerek, bunu normal siyasi argümanlarla değil, daha çok siyaset dışı araçlarla ve darbeci bir mantalite ile yapmayı hedeflemiştir. Artan kurumsal ve kamusal gücü sebebiyle bürokratik ve resmî organizasyonlarda iktidar olmaya yönelmiştir. Söz konusu aşamaya geçişin, 1980’lerin ortasından itibaren üniversiteye hazırlık kursları, dershaneler ve yurtların açılışıyla başladığı anlaşılmaktadır. Ancak bu süreç içerisinde de 1995’lere kadar yapı adeta bir görünmezlik evresine bürünerek medyatik tartışmaların dışında kalmaya çaba göstermiştir. Tartışmaların odağına yerleşmesi ise öncelikle hareketin artık kamusal alanda ve kurumlarda dikkatlerin ve tartışmaların dışında kalamayacak bir büyüme ve yayılma göstermesiyle ilişkilidir. Diğer taraftan tartışmalar, grubun sadece sosyal ve kültürel alandaki etkisinin değil, aynı zamanda devletin kritik kurum ve yapılarına nüfuz ettiğine ilişkin emarelerin iyice ortaya çıkmasıyla da artmıştır.

Son derece karmaşık ağ ilişkileriyle eğitimden medyaya, sağlıktan finans sistemine kadar hemen her alanda büyük bir güç haline gelen Gülenist yapının, kendine ilişkin algıyı da kavramlar üzerinden sürekli rötuşlaması dikkat çekici olmuştur. Bu çerçevede, "Gülen Hareketi”, “Gülen Cemaati”, "Hizmet Hareketi” ve "Hizmet”, gibi adlandırmalarla kamuoyunda artık dinî bir grup ya da cemaat çağrışımı yapmayan sıfatların tercihi anlamlıdır. Esasen paralel yapı içsel halkalarda dinsel bir örgüt gibi çalışırken, dişsal halkalarda sivil sosyal bir hareket gibi strateji izleyerek yapısal bir takiyye siyasetini öteden beri uygulamaktaydı.

Gülenist yapının iç ya da dış halkalarında genişleyen aidiyet ve bağlanma sebeplerinden biri de Gülen'in içeriğine vecdî, mehdici beklentilerin katıştırıldığı konuşma ve vaazlarına atfedilen dinselliktir. Gülen, aslında diğer İslami grupların sık sık mendilli ağlama sahnelerini kıyasıya eleştirdiği görüntülere rağmen, kendi grubu- 
nun mensuplarınca karizmatik bir vâris olarak karşılanıyor, çoğu zaman mahrem mahfillerde ama zaman zaman aşikâre bir şekilde mehdilik pozisyonuna yakıştırılıyordu. Gülen'in eserlerinde ve vaazlarında kullandığı dil, geleneksel âlim tipine hiç uymamaktadır. Eğitimi ve retoriği bakımından İslami geleneğin ulema tipolojisine ters düşen Gülen, bazılarınca İslami ilimlere vâkıf bir âlim ile modern Müslüman aydın arasında bir ara kategori olarak sunulmak istenir (Kömeçoğlu, 2000, s. 165166). Ancak esasta bir vaiz olan Gülen'in klasik âlim veya modern aydın kategorilerine de denk düşmediği açıktır. Dolayısıyla gerçekte Gülen'in etki gücünü, karizmatik liderlikten ziyade, temsil ettiği yapının geleneksel cemaatlerin aksine toplumsal sermayesinin genişlemesinden aldığı söylenebilir. Nitekim sosyo-ekonomik ve bürokratik gücüyle birlikte uluslararası alandaki faaliyetlerinin daha çok şehirli genç kuşakların ve orta sınıfların ilgi alanına girmesi bu durumu tasdik eder.

Öte yandan, hareketin 1990'larla birlikte ABD'de kümelenen ve küresel güçlerle istihbarat örgütlerince kontrol edilerek yönlendirilen bazı yeni dinî hareketlerde ve Moonculuk'ta olduğu gibi uluslararası bir şebeke haline gelmesi, basitçe karizma kavramıyla açıklanamayacak kadar karmaşık ilişkileri gerektirmektedir. Bununla birlikte, yapının iç halkalarındaki ya da piramidin çatı organizasyonundaki bütün faaliyetleri kendi denetimi ve kontrolü altında tutacak kadar örgütçü bir yol izlediği anlaşılmaktadır. Zaman zaman "Gülen'in cemaati üzerinde mutlak kontrole sahip olmadığı" hususundaki değerlendirmelerle birlikte, gerçekte uzun süredir yurt d1şında yaşaması ve yaşının ilerlemesine rağmen hareketle ilişkili bütün faaliyetlerden haberdar olduğu ve bunlara sürekli olarak müdahale ettiği bilinmektedir (Çakır \& Sakall, 2014, s. 22-23).

Kamusal alanda sempatizanlarının artmasıyla "camia” olarak tanımlanan ve tartışılan Gülenci yapılanmanın zamanla harekete katılım veya çıkış için sınırlarının belirsiz hale gelmesinden söz edilse de, örgütlü dinsel yapı döneminde, yakınlık veya uzaklık durumuna göre kişilerin tasnif edildiği bilinmektedir. Bu çerçevede, yapının iç çekirdeğinden dış halkalara doğru, "talebe, kardeş, dost ve müstaid (dost olmaya eğilimli)" gibi kavramlar kullanılmıştır. S. Nursi'ye dayandırılan bu sınıflandırmanın son kategorisinin Gülen tarafından eklendiği belirtilmektedir. İkinci ve üçüncü dönemde paralel yap1, yeni üyelerini dershaneler üzerinden devşirmiştir. Dinî kavramlarla katılımın teşvik edildiği hareketin içsel yapısında özellikle de yurt dışı eğitim kurumlarında görev alanları için ifade edilen "adanmışlar" kavramı, toplumsal meşruiyet için kullanılmış ve öne çıkarılmıştır (Kömeçoğlu, 2000, s. 148, 192).

Gülenist yapının ilk ve ikinci dönemindeki toplumsal tabanı, sosyal adaletsizlik ve problemlere karşı tepkilerin karakterize ettiği bir topluluğa dayanmaz. Dolayısıyla hareketin mensupları sosyal eşitsizlikler ve adaletsizliklerden mağdur olmuş 
kesimlerden ziyade, üniversiteliler, orta sınıf esnaf ve büyüme yolundaki iş adamlarından oluşur. Üniversite mezunlarını yurt içi ve yurt dışı okullarında adanmışlar adı altında istihdam eden örgüt, iş adamlarını da ulusal ve uluslararası yatırım ve ilişkilere yönlendiren bir güç olarak kendi ağ sistemine katmıştır (Kömeçoğlu, 2000, s. 151-153). Gülenist hareket iş adamlarının ekonomik gücünden, iş adamları da örgütün ekonomik, sosyal ve siyasal sermayesinden karşılıklı olarak yararlanma temelinde birbirini beslemiştir. Bu karşılıklı besleme ilişkisi neticesinde tarafların her biri güçlerini artırırken, gerçekte hareketin toplumsal ve siyasi alanda etkili bir örgüt olarak hegemonyası artmıştır.

Hareketin iç yapısıyla ilgili olarak Yavuz (2005), çekirdeğinde yaklaşık otuz kişilik "büyük ağabey" kadrosunun bulunduğunu ifade eder. Bunların bir kısmı Gülen'in en yakın dostları ve talebeleridir. Büyük saygı ve itibar sahibi olan bu çekirdek kadro, günlük politikalar konusunda da danışma merkezidir. Örgütün ikinci tabakası, faaliyetleri finansal açıdan destekleyen esnaf ve iş adamları grubudur. Bunlar, Gülen'in hareketle somutlaşan hedeflerini "himmet" ve destek yoluyla "eser" faaliyetlerinin oluşturulmasına katkıda bulunurlar. Bu kesim, aynı zamanda, ülkenin her tarafına yayılmış çok sayıdaki vakfın mütevelli heyetlerini teşkil ederler. Sonuncu tabaka ise, Gülen'in hedeflerini paylaşan ama bunların gerçekleştirilmesine katılmayan sempatizanlardır. Bu kategori, okul, gazete ya da yurt gibi eserin korunmasıyla ilgili olup (Yavuz, 2005, s. 256) yapının iyi ilişkiler kurduğu tabakayı temsil eder.

Gülenist yapının içe ve dışa yönelik ikircikli karakteri nedeniyle, klasik cemaat-birey ilişkisi de sürekli tartışma alanı içinde olmuştur. Bu noktada geleneksel dinî grupların durumu bellidir; onlar genellikle karizmatik liderlerin etrafında belirli yazılı metinleri sürekli tekrar etmeleri dolayısıyla şeyh-mürit ilişkisini yeni bir form altında yeniden üreterek belli ölçüde bireyselliğin gelişmesine engel olabilmektedirler. Gülenist hareketin dışa yönelik liberal ve 1lımlı söylemine karşlık, kendi içinde bireysel hak ve özgürlükleri geliştirmediği, grup içi disiplin ve hiyerarşik yapısıyla bireyin yerine önceliğin cemaate verildiği bir gizil hareket görünümündedir. Hareket, liderin otoritesine dayalı organizasyon biçimiyle, üyelerin gündelik hayatları ve bireysel ilgileri üzerinde sıkı kontrol mekanizması yoluyla hiyerarşik bir yapılanmaya sahiptir (Bodur, 2003, s. 34). Cemaat içi tabiiyet ilişkisi, eğitimli üniversite mezunu ve üst düzey mesleklerde çalışan kişilerde bile, ağabeyleri sorgusuz otorite kabul etme tavrı, eleştirel düşünce ve sorgulama gibi kimi bireysel özellikleri yadsır. Gülenist yapı, bu sisteme uygun olarak, devlet içinde yerleştirdiği mensuplarından resmî hiyerarşiye değil de örgütsel hiyerarşiye göre sadakat istemesi nedeniyle devletin varlı̆̆ için giderek artan bir tehdit oluşturmuştur. 


\section{Cemaatten Paralel Yapıya; Kurumsal İşgal}

\section{Gülenist Yapının Güç ve Meşrulaştırma Zemini: Eğitim}

Cemaatin eğitim alanına yönelik faaliyetlerinin temelinde, Gülen'in "altın nesil yetiştirme” projesi yer alır. Bu projenin özel okulların yaygınlaşmaya başladığı 1980 sonrasında siyasal otoriteler ve iktidarlarla kurulan iyi ilişkilerle geliştirildiği bilinmektedir. Söz konusu okulların en önemli özelliği, daha çok fen bilimleri ağırlıklı olmasıdır. Okulların cemaat açısından önemi, bir yandan seçkin üniversitelere yönlendirilmiş öğrencileri yetiştirirken, diğer yandan işadamları, üst düzey görevli, memur ve bürokratları kendi etki alanına çekebilme potansiyelidir. Cemaat, geniş bir kitleyi yurt içi ve yurt dışında görevli adanmış öğretmenlerin fedakârlıklarıyla işlenmiş hikâyeleri etrafında endoktrine ederek takipçilerini bu okulları ayakta tutmak için seferber etmiştir. Okullar, Gülenist yapının uluslararası sahada kendini refere ettiği ana hareketlilik kaynakları olmuş, sadece öğretmenler ve öğrencilerin değil aynı zamanda işadamlarının da ticari bağlantı ve teşvik için kullanıldığı bir boyut olarak öne çımıştır. Bu okulların özellikle yurt dışında ticaret yapmak isteyen kişiler için referans olması, iş adamlarının okullara ve cemaate yönelik yardımlarını ve irtibatlarını artıran bir unsur olmuştur.

Gülenist yapının eğitim sektöründe gerçekleştirdiği atakların çok önemli sonuçları olmuştur. Her şeyden önce eğitim alanında yaptığı yatırımlar, hareketin sosyal sermaye kaynağı olarak işlev görmüştür. Siyasetçi, yönetici, bürokrat ve iş adamı gibi seçkinlerin çocuklarının bu okullara gitmesini teşvik eden şey, okulların kaliteli eğitim verdiği düşüncesi olmuştur. Böylece Gülenist yapı, ilgili okullarda her ne kadar dinî eğitim vermese de sözde dinî-millî değerlere bağlı adanmış öğretmenlerin çalıştırdığı okullar sayesinde hem insan kaynağı bakımından sıkıntı çekmiyor, hem de toplumda etkili yönetici, bürokrat ve iş adamlarıyla özel bir bağ kurma firsatı yakalıyordu (Yavuz, 2005, s. 260-261).

Cemaatin okulları yabancı dil ve fen bilimlerinde gösterdiği yüksek başarıdan dolayı pek çok kesim tarafından taltif edilir ve teveccüh görürken, diğer İslami gruplar ve milliyetçi çevreler tarafından özellikle eğitimin içeriği ve hedefleri bakımından yoğun eleştirilere uğradı. Okulların dinî niteliğine ilişkin eleştiriler, daha çok İslami gruplar ve cemaatlerin altını ısrarla çizdiği ve bu yüzden harekete şüpheyle bakmalarını gerektiren bir husus olarak öne çıkmıştır. Kendini dinî bir cemaat gibi lanse eden Gülenist yapının okulları, gerçekte İslam'ı tebliğle alakası olmayan, okul ve yurtları dinî simge ve özelliklerden arınmış mekânlardı. Eğitim dili İngilizce olan bu kurumlarda ayet ve hadis gibi İslami unsurlara yer verilmiyor, eğitim dinî bir müfredata dayanmıyor, sorunlar İslam'a referansla değil de bilimsel açıklamalara bağlı olarak açıklanıyordu (Kömeçoğlu, 2000, s. 171-172, 188). Öte yandan, Cema- 
at okullarının stratejik amaçlara yönelik yapılanmasıyla birlikte buralarda verilen eğitimin niteliği konusunda da ciddi eleştiriler yapılagelmiştir.

Gülenist yapının eğitim alanında kullandığı en önemli zemin ise "dershane" denilen özel hazırlık kursları düzeyinde olmuştur. Cemaatin hemen her il ve ilçede öğretmenleri ve özel programları ile yüksek başarı yakalayan lise ve üniversiteye hazırlık dershaneleri, çok büyük bir öğrenci kitlesini kendine çekerek, adeta tekel haline gelmiştir. Dershaneler, sadece hazırlık kursları değil, spor, uygulamalı eğitim, kitap dağıtımı ve sohbet gibi çok yönlü faaliyetlerin alanı haline gelmiş, öğrenciler aynı zamanda cemaatin benimsediği programlara katılmaya teşvik edilmiş, belirlenen hedeflerin içselleştirilmesi için seçilen öğrenciler özel çalışmalara tabi tutulmuşlardır (Yavuz, 2005, s. 262-263). Sinavlara hazırlık kursları olarak dershaneler özel işlevlerinin dışında, yapının günlük gazetesi Zaman'ın abone sayısını artırma ile yurtlarda ve okullarda yeni kadroların istihdam edilmesinde ana kaynak işlevi görmüştür.

\section{Hegemonyanın Ekonomi ve Medyadaki Yansımaları}

Gülenist yapı, özellikle seksenli yıllardan sonra sosyoekonomik değişimin yeni parlayan orta ve üst sınıflarını içine alan bir örgütlenmeyle kendine özgü bir güç odağ1 olmuştur. Bu süreçte kurduğu çok sayıda şirket ve kurum ağılla devasa mali kaynakları kontrol etmeye başlayan örgütün sosyoekonomik bir güç olarak piyasada önemli bir aktör haline gelmesi, toplumsal alanın diğer kurumlarında da etkinliğini artırmıştır. Finansal kaynağı oluşturan tüccarlar ve küçük ölçekli sanayiciler Gülen'in hareketini desteklemişler, bununla birlikte gelişen ağ sisteminin yararlarını da devşirmişlerdir. Bu bakımdan, örgütün içeride ve dışarıda yürüttüğü sosyal faaliyetleri ve eğitim faaliyetlerini mali açıdan desteklemek amacıyla 1996'da Asya Finans şirketi kuruldu; iş adamları (İŞHAD) ve sanayicileri (HÜRSİAD) örgütleyen derneklerle birlikte paralel yapı güçlendirildi (Yavuz, 2005, s. 260).

Türkiye'nin 1980 sonrası içine girdiği piyasa ekonomisi ve neo-liberal politikalar, firsatlarla dolu yeni tüketimci toplumsal atmosfer içinde, cemaatlerin de ilgisini çeken yeni iktidar alanını oluşturuyordu (Yankaya, 2014, s. 71). Bu çerçevede, muhafazakâr iş adamlarının ihtiyaç duyduğu yüksek kazanma arzusu ve iç ve dış pazarlara açılma isteği, Gülenist hareketin küresel pazarlara ulaştırmayı vaat eden yapısı ile kolayca birleşiyordu. Ancak bu durumu Weber'in Protestan Ahlakı ve Kapitalizm ilişkisini açıklayan kavramlarıyla ele almak, cemaatin temel mantığını göz ardı etmek anlamına gelir. Türkiye'de pek çok araştırmacı, bu bakımdan, iktisadi boyutu fazlasıyla gelişmiş Gülenist yapıyı Weberci tezlerle açıklamak niyetindedir (Yanka- 
ya, 2014, s. 31). Ancak bu çalışmaların çoğunda, Protestanlaşma olgusu sosyolojik düzeyde tartışılmaktan çok yüzeysel değerlendirmeler için araçsallaştırılmıştır. Cemaat dinsel söylem düzeyinde diyalogcu Protestanlaşmış bir anlayışı tetiklerken, iktisadi anlamda kapitalist bir kalkınmadan çok, kendi organizasyon ve faaliyetlerini güçlendirmeye yönelik çalışıyordu. Bu durum, Protestan ahlakındaki bireysel kaderci, çileci ve kişisel ahlaki sorumluluk gibi değerlerin içselleştirilmesi olgusundan çok farklı bir şey olup, anakronik bir değerlendirmeye de uygun değildir.

Gülenist hareketin hegemonik güç haline gelmesinde en etkili araçlardan biri de medya olmuştur. Gazete, dergi, radyo ve televizyon yayıncılı̆̆ı gibi medyanın bütün alanlarında cemaatin ulusal ve uluslararası alanda çok profesyonel ve etkin bir şekilde faaliyet gösterdiği bilinmektedir. Kamuoyunu etkileme ve yönlendirme aracı olarak medya Gülen'in çok önem verdiği bir argüman olduğu için medya yoluyla hem kendi güdümünde paralel bir toplumu hem de entelektüel sermayeyi oluşturma yoluna gitti. Paralel yapı, gerek mensupları gerekse toplumsal kesimler üzerindeki etkisini artırmak için medyanın gücünü alabildiğine yaygın ve etkin biçimde kullanan bir hareket olarak öne çıktı. ${ }^{7}$ Hegemonyanın en önemli unsuru olarak ekonomi ve medya alanında örgütlenme, Gülen'in genel stratejisinin bir parçası olarak görünmektedir. Gazetesinin tiraj artışına kadar pek çok konuyu bir ibadet boyutunda talimatlarla teşvik eden Gülen, ekonomi alanında da geniş bir ağı kendi tekeli ve denetimi altında tutmak için özel taktikler geliştirir. Öyle ki bu durum, ikamet ettiği Pensilvanya'daki malikânesinin pek çok kesimden insanın yanı sıra özellikle iş adamları tarafından da bir ziyaret yeri haline getirilmesinden anlaşılmaktadır.

Gülenist yapının artık karşı-kamusallıktan hegemonik yapıya geçtiği evrede, medyanın daha çok operasyonel amaçlarla kullanıldığı görülür. Paralel yapının televizyon ve gazetelerinde dinî hassasiyetlerle ilgili yayın politikası çoğu zaman sekte-

7 Zaman gazetesi, Özal, Demirel ve Çiller hükûmetlerinin de desteklerini alarak yalnızca Türkiye'nin değil, aynı zamanda, Müslüman Türklerin bulunduğu 13 farklı ülkede de basılan, uluslararası ayağı olan bir yayın ağını temsil eder. 2002 yılına gelindiğinde gazete, Türkiye'deki en büyük beşinci gazete konumuna ulaştı; bu dönemden sonra sürekli olarak ilk üçün içinde yer alan gazete, bu tirajı yaygın abone stratejisiyle sürekli olarak yüksek tuttu. Farklı kesimlerden ve özellikle liberal isimlere yer veren gazete, böylelikle farklı bir profil çizerken, çoğu zaman siyasi görüşleri ve duruşları önceden kestirilemez özellikte yayınlar yapmıştır. Türkiye'nin Avrupa'ya entegrasyonu fikrini onaylamış, ama bir dönem imam-hatip okullarının ortaokul kısmının kapatılmasına çok fazla tepki göstermemiştir. Gülenist yapının, Zaman gazetesi dışında bazı gazete ve dergiler ağına da sahip olduğu bilinmektedir. Öte yandan örgüt, Samanyolu adıyla bilinen bir ulusal televizyon kanalı dışında yine bazı ulusal ve yerel TV’ler, Dünya ve BURÇ gibi radyo istasyonları kurdu. Hareket ayrıca Sızıntı (bilimsel aylık dergi), Ekoloji (çevre dergisi), Yeni Ümit (ilahiyat dergisi), Aksiyon (haber dergisi) ve The Fountain'e (İngilizce dinsel yayın) sahiptir (Yavuz, 2005, s. 258). Zaman gazetesinin sürekli en yüksek tiraja sahip görünmesinin temelinde ise, iş adamlarının çok sayıda abonelikle gazetenin her yere ulaşmasını teşvik etmeleri, dershane öğrencilerinin zorunlu abonesi gibi yaygın taktikler yatmaktadır. 
ye uğramış, sır dizileri gibi daha çok çarpık din anlayışını ikame etmeye yönelik yayınlarda geleneksel Sünni kabullerin dışına çıkılmış, batıni, ezoterik ve kaderci bazı algıların yerleşmesine yol açılmıştır. Gülenist medyanın ekonomik gücü sayesinde, diğer İslami grupların ve yayınevlerinin aksine çok profesyonelce ve sistemli bir faaliyet yürütmesi dikkatlerden kaçmaz. Pahalı yapımlar, diziler, haber ve tartışma programlarıyla paralel medya, cemaatin küreselleşen yüzünü “yerel”e taşıyarak, dünyanın dört bir yanındaki okullarla ilgili belgeseller, haberler, Türkçe olimpiyatları gibi faaliyetler üzerinden kendi müntesiplerini ve toplumu dönüştürmenin bir zemini olarak kullanılmıştır. Paralel medyanın özellikle Ergenokon ve Balyoz gibi 17 Aralık Darbesi'nden önceki olaylarda sergilediği aktif yayınlar, bu operasyonlardaki örgüt etkisini ortaya koymuştur. 17-25 Aralık Darbe Girişimi'nden sonra ise Gülenist medya, tam cephe halinde, Türkiye'nin seçilmiş meşru hükûmetine karşı taarruza geçmiş, çarpık algılar eşliğinde kamuoyunu maniple etmeye çalışmıştır.

\section{Sivil Toplumun Dernekler ve Vakıflar Üzerinden Paralelize Edilmesi}

Gülenist yapı, başından itibaren, ideolojik düzeyde devleti hedefleyen ve siyasi dönüşümü arzulayan bir hareket olmadığını deklare etmiş görünüyordu. Bu çizgide özellikle de Siyasi İslami hareketlerden kendilerini ayırt etmeye özen göstermişler ve Ilımlı İslami bir eğilimi temsil ettiklerini savunmuşlardır. Ancak pratik anlamda cemaat, ikili stratejisinin bir gereği olarak, başından itibaren de iktisadi, siyasi, kültürel alanlarda örgütlenme fırsatlarını değerlendirmekten geri kalmadı. Kabul etmek gerekir ki yapının bu çerçevede gelişme göstermesinin sebeplerinden birisi de Türk siyasal kültüründeki otoriter laiklik uygulamalarının ters etkisi olmuştur. Ancak toplumsal alandaki yaygın ve güçlü etkinin asıl itici motifini, seksenli yıllardan itibaren gelişen demokratikleşme, çoğullaşma ve yeni şehirli orta sınıfların ortaya çıkışını kolaylaştıran sosyo-ekonomik zemin tetiklemiştir. Kuşkusuz bu durumdan yararlanan yalnızca Gülenist grup değildi, nitekim bazı cemaatler bu genişleyen sivil alanda sosyal, mesleki ve siyasi görevler alarak alanlarını pekiştirdiler. Türkiye'nin ve dünyanın içinden geçtiği dönüşüme son derece değişken yapısıyla kolayca uyum sağlayan Gülenist yapı, neoliberal döneminin fırsatlarından azami şekilde yararlandı (Yankaya, 2014, s. 66).

Sivil toplum alanında örgütlenme potansiyelinin zaman içerisinde imkân ve öneminin artması, özellikle kamusal alana açılma eğilimindeki dinî grup ve hareketleri cezbetmiştir. Türkiye'de değişim stratejisini siyaset üzerinden veya birey ve kültür üzerinden yürüten bütün dinî grup ve hareketler de bu alanda aktif olmayı hedeflemişlerdir. STK'lar üzerinden cemaatlerin stratejik kazanımlar elde etmesi, sivil toplumu cemaat mensupları için işlevselleştirmiştir. Bu durum, en çok siya- 
set kurumuyla pragmatik iş birliği ve ittifakların önünü açmıştır. Nitekim Gülenist yap1 da apolitik olduğunu deklare ettiği zamanlarda dahi siyasetle oportünist bir ilişki kurmaktan kaçınmamıştır. Devlet makamlarıyla ve politikacılarla ilişki kurarak yapının sosyal tabanını genişletme arzusu, bu yönelimin temel sebebini oluşturmuştur (Yavuz, 2004, s. 67-68). Gülenist hareket için, bu ilişkide sosyal tabanı genişletmekten çok, resmî kurumları içeriden ele geçirmeye yönelik gizli stratejisi daha özel bir anlam taşıyordu.

Sivil toplum alanındaki örgütün en önemli çıkışlarından biri, “Türkiye Gazeteciler ve Yazarlar Vakfı” aracılığıyla yaptığı çalışmalardır. 1994 yılında kurulan Vakıf, cemaatin ulusal ve uluslararası varlığını meşrulaştırmada önemsediği "Birlikte Yaşama Tecrübesi”ni akademik ve entelektüel alanda savunmaya yönelik faaliyetlerde bulunmuştur. TGYV; faaliyetlerini Abant Platformu, Kültürlerarası Diyalog Platformu, Diyalog Avrasya Platformu, Medialog Platformu aracılığı ile yürütmüş, toplantı ve sempozyumlar düzenlemiştir. Abant Platformu, periyodik organizasyonlarda demokrasi, insan hakları, devlet, laiklik, küreselleşme, Türkiye'de İslam gibi konuları tartışarak deklarasyon yayımlamıştır. Kültürlerarası Diyalog Platformu, teröre ve savaşlara karşı ortak çözümler üretmeyi; Diyalog Avrasya Platformu, Doğu Avrupa ve Orta Asya ülkelerinin birbirleriyle iletişimine katkıda bulunmayı; Medialog Platformu ise medya alanında bir diyalog kültürü oluşturmayı amaçlamıştır (Şentürk, 2011, s. 265-266). Bu faaliyetlerde toplumun farklı kesimlerinden kişileri bir araya getirmeye çalışan hareket, hem entelektüel isimler üzerinden cemaati meşrulaştırıyor, hem de Türkiye'nin ulusal ve uluslararası siyasetinde söz sahibi olmanın yollarını açıyordu.

Bu tür faaliyetlerle hareket her ne kadar retorik olarak siyasal güç devşirmeye karşı olduğunu açıklasa da, bürokraside ve devletin stratejik kurumlarında gerçekleştirmiş olduğu sızma ve örgütlenme nedeniyle, sivil alandaki faaliyetlerine de daima şüpheyle yaklaşılmıştır. Üstelik sivil toplum alanında artırdığı güçle, siyasal alanda da aktif bir özne olmaya başlaması üzerine artık hareketin cemaat olmaktan çıkarak siyasal bir aktör haline dönüştüğü konusundaki kanaatleri güçlendirmiştir. Gülenci yapının sivil toplum alanında genişlemesi, kamusal alanda diğer dinî grupları etkisizleştiren bir büyüme gerçekleştirmesi, dinî gruplarda olduğu gibi, toplumun diğer siyasal grupları tarafından da endişeyle karşılandı. Bu olgu, paralel kültürün veya yapının ana gövdeye rahatsız edici bir tahakkümü olarak görüldü. Bu durum, belki de Türkiye'de siyasetin kurumsallaşma zayıllı̆g, siyaset dışı kurum ve yapıların ise yeterince güçlü olmayışından doğan bir boşlukla ilgiliydi ve bu boşluk büyük ölçüde Yapı tarafından dolduruldu. Hareketin sivil sosyal alanda girdiği örgütlenme çabası, cemaat yapısının sosyal kültürel ve sivil bir yapıya dönüşmesini 
gerektirirken, tam aksine sivil alan paralel örgüt tarafından dönüştürülmeye çalışılmış, yegâne egemen güç ve söz sahibi olmak için sivil toplum araçsallaştırılmıştır.

Resmî adlandırmasıyla "Paralel yapı"nın kurumlaşma aktivitesi, devletin kendi kurumsal potansiyelinin toplumsal gelişme ve taleplerin gerisinde kalması ve bunlara cevap üretememesiyle ilişkili olarak artmıştır. Ancak devletin kurumsal arzı toplumsal beklentilerin tamamını karşılayacak seviyeye erişse de, dinî sosyal alanda cemaatlerin varlığının ortadan kalkması zordur. Zaten böyle bir beklentinin pozitivist seküler yönünü de göz ardı etmemek gerekir. Diğer yandan, cemaatlerin sivil toplum gibi kamusal alana yönelmeleri ve orada aktif hale gelmeye çalışmaları da belli bir meşruiyet temeline sahip görünmektedir. Hatta bu bağlamda cemaatleri sivil toplum kuruluşları gibi görme eğilimi öne çıkmakta ve tartışma konusu olmaktadir. Ancak sivil alanda bir grubun diğer cemaatler ve sivil toplum kuruluşlarının aleyhine hacmini büyütmesi ve hegemonik bir güç haline gelmesi, toplumsal dünyada olduğu gibi diğer gruplar ve cemaatlerle rekabet ilişkisini de bozacak bir çatışma ortamını tetikler. Aynı zamanda sivil alanı hegemonik bir şekilde işgal eden bir hareket, bütün sosyal gruplara karşı hukuki güvenceyi garanti eden devlet mekanizmasında da endişelere yol açar. Esasen burada dile getirilmesi gereken soru şudur: Gülenci yapı, bu örgütlenme tarzı ve hegemonik eğilimleriyle gerçekten sivil alanı temsil eden bir hareket kategorisinde miydi? İdeolojik, hiyerarşik ve organizasyonel olarak bakıldığında paralel yapının gerçekte demokrasi ve sivil toplumu destekleyen bir grup vasfında olmadığı anlaşılmaktadır (Yavuz, 2005, s. 273). Bir başka deyişle Gülenist yapı, kamuya yansıyan yüzünde sivil demokratik alandaki fırsatları avantaja dönüştürmeye çalışan bir hareket gibi davranırken, içsel yapısında ise kapalı, hiyerarşik, ezoterik karakteristiklerinden dolayı diğer toplumsal kesimlere güven vermemiştir.

\section{Siyasal Alanın Siyaset Dışı Araçlarla İşgali}

Cemaat ve grup oluşturma eğilimi dinî sistemlerin temel bir özelliği olup, bu bakımdan dinî grupların gündelik hayatla birlikte kamusal ve siyasal alana ilgisi de kaçınılmaz hale gelmektedir. Siyasal ilgi, büyük ölçüde, dinlerin dünya karşısındaki tutumları ve kamusal alandaki pratiklerinde gelişen muhtevalarıyla da belirlenen bir durumdur. Öte yandan toplumsal süreçlerin, dinî gruplar ve organizasyonları harekete geçiren siyasal bir dinamik olduğu da gerçektir. İslam dünyası, mezhep ve düşünce gruplarının büyük oranda siyasal, sosyal etkileşim ve çatışmaları belirlediği bir tarihselliği içerir. Sünni geleneğin ağırlıklı olduğu tarihimizde dinî oluşumların, mezhep ve tarikatların siyasi alanla ilişkileri, özellikle Cumhuriyet sonrası süreçte, sistemin yapısına göre değişen eğilimler ortaya koymuştur. Bu bakımdan, 
geleneksel nitelikli ya da gelenekle irtibatlı yeni dinî grupların siyasi alana daha çok pragmatik bir yakınlık duydukları söylenebilir. Nitekim siyasetle oldukça ilgili olan Nakşibendi geleneği de dâhil olmak üzere dinî grupların siyasi stratejileri öncelikle dinî özgürlüklerin teminatı ile kendilerine yeni alanlar açarak yasal, kültürel ve sosyal zeminde serbestlik üzerine kurulmuştur. Bu yüzden tarihsel pratikte bilinen dinî lider tipolojisinin devlete talip olma ya da devleti ele geçirmekten çok, iktidarla barışık yaşama ve bunun avantajlarını devşirme stratejisine göre yol aldığı görülür.

Said-i Nursi'nin siyaset karşıtlığıyla ilgili meşhur bir sözüne dayandırılan Nurculuğa özgü siyasi ilişkisizlik durumu, çoğu zaman sosyolojik ve tarihsel pratiği yansıtmayan ve yanıltan bir iddiadan öteye geçmemektedir. Nurculuğun karakterine de, diğer İslami gruplarda olduğu gibi, Batı karşısında yaşanan bilimsel, siyasal, askerî ve sosyoekonomik yenilgilere karşı cevap verme arayışı ve tepkisellik siyasi bir renk katmıştır. Ancak siyasetten berî olma retoriği, Nurcu grupların gündelik siyasetin etkilerinden uzakta örgütlenmelerini kolaylaştırmıştır. Bununla birlikte siyasal tarihimiz, bütün dinî gruplarda olduğu gibi, hemen bütün kesimleriyle Nurcuların da siyasetle içli dışlı olduğunu göstermiştir. Nitekim Gülenist yapı da başlangıcından itibaren kendini hep siyaset üstü gösterme çabasında olmuş, ancak Gülen'in daha ışık evleri ve yurtlarla başladığı örgütsel faaliyetlerinden itibaren eğitim, medya, finans gibi sosyal, kültürel, ekonomik ve sivil alandaki faaliyetlerinde siyasetle doğrudan ve dolaylı ilişkiler kurmuştur. Aktay’ın da belirttiği gibi, cemaat aslında siyasal idealleri olan örgütlü bir dinî yapıdır, bunun temel kanıtı ise tamamen siyasal bir ideal olan eğitim yoluyla yeni bir nesil yetiştirilmesi programıdır. Nitekim Gülen'in biyografisinde de siyasi pozisyon almanın örneklerini oluşturan tavırlar çok belirgindir (Aktay, 2004, s. 179, 188). ${ }^{8}$ Gülenist yapının süreç içerisinde siyasallaşmasını artıran unsurların başında, ekonomik, sosyal ve kültürel sermayesinin yükselmesi gelmiştir. Okullar, dershaneler, üniversiteler, dernekler, şirketler, ekonomik yatırımlar gibi kurumsal düzeyde gelişen devasa yatırımlar ve bunları siyaseten koruma ihtiyacı, hareketi büyük ölçüde koruyucu siyasi ittifaklar ve operasyonlar içine çekmiştir. Görünürde açık bir siyasi parti oluşumuna sıcak bakmayan paralel yapı, siyasi görüş farkına bakmaksızın, daima güçlüye ve iktidara oynamıştır. Bu durum, grubun kendine özgü ilkeler ve prensiplerin izinde yürümekten ziyade, kendi çıkar ve kazanımlarını koruma uğrunda her türlü ittifaka dâhil olabilen oportünist bir karaktere sahip olduğunu işaret eder. 
Gülen'in 28 Şubat 1997 Postmodern Darbesi'nde İslamcıları karşısına alan pozisyonu ise, oportünist siyasileşmenin bir göstergesi gibidir. 28 Şubat'ta Refah Partisi'ne ve bazı İslami gruplara karşı başlatılan aleyhteki kampanya sırasında Gülen, Refah Partisi'ni gerilim yaratmakla ve radikallikle suçladı. Medyada sürekli olarak “öteki” İslâmcılar'dan farklarını öne çıkardı ve "hoşgörü”, “Türk-İslam'ı”, "Siyasal İslâm'a karşı kültürel İslam” ve benzeri terimlere atıflarda bulundu (Aktay, 2004, s. 192). Gülen'in yaklaşımlarındaki bu tarz, anti-demokratik muktedir yanlısı siyaset ile dinî alandaki batıni aşırı yorumları diğer İslami grupların şiddetli tepkilerine sebep olmuştur. Bu durum, cemaatin kamusal alandaki liberal görünümlü siyasal söyleminin de güven verici olmadığını teyit etmiştir.

Bazı yaklaşımlarda, Gülen'in Amerika'ya gittikten sonra fikirlerini değiştirdiği, liberal düşünceye, küreselleşmeye ve demokrasiye daha açık hale geldiği iddiası vardır. Ancak Gülen'in biyografisinde bu tür dönüşler ve manevralara rastlamak şaşırtıcı olmadığı için, bu tür söylem farklılıklarının da operasyonel sebepleri bulunmaktadır. Nitekim bunun en makul açıklaması, liberal retoriğin paralel yapının uluslararası imajını korumaya yönelik bir stratejiye uygun olmasıdır. Bu tür söylemler, aslında uluslararası ölçekte devasa kurumlar ve işletmeler ağıyla yaygınlaşmış ezoterik bir dinî hareket gibi algılansa da, yapının şeffaf olmayan illegal yapısının güvensizliğinden kaynaklanacak riskleri bertaraf etmeye yönelik girişimler olarak okunabilir. Bu bağlamda Gülen, "Gazeteciler ve Yazarlar Vakfı"nı yönlendirerek bütün grupları içine alan birtakım konferanslar, toplantılar ve diyalog sempozyumları düzenlemiştir. Söz konusu toplantılarda, Türkiye'nin sorunlarını tartışmak ve çözümler sunmak üzere, çok farklı kişi ve gruplar bir araya getirildi. Vakfın 1998 ile 2001 arasında "İslâm ile laiklik arasındaki ilişki; din ve devlet; demokrasi ve insan hakları; çoğulculuk ve uzlaşma” konularında düzenlediği Abant toplantıları, Türkiye'deki belli tartışma konularını ve hatta siyaseti bile etkiledi. Bu konferanslar yoluyla birçok bilim adamı, aydın ve politikacıyı bu sorunları tartışmak ve muvafakat oluşturucu beyannameler hazırlamak üzere bir araya topladı (Yavuz, 2004, s. 68-69, 86).

Gülen, dış siyasete yönelik, özellikle İran'la ilişkiler konusunda daha çok ulusalcı laikçi zihniyetle aynı güvensizlik eğilimini paylaştı. Türkiye'nin İslâm dünyasında tarihî liderlik rolü oynayacağı umudunu ve ümmet düşüncesini hep uzak bir hayal olarak gördü. Bunun yerine AB gibi Batılı kurumlarla ve ABD ile yakın ilişkilerin sürdürülmesini savundu, Batı ile çatışmaktan kaçınmaya çalışarak, kendisini Arap dünyası ve İran'dan uzak tutmaya çalıştı (Kösebalaban, 2004, s. 219-220). Gülenist cemaatin dış politikaya ilgisi, uluslararası bir hareket olarak ABD'nin küresel siyasetine ve stratejisine uygun bir planlama içinde yer almasıyla ilişkilidir. Dış politi- 
ka konusunda, diyalog faaliyetleri dışında, "Ilımlı İslam" gibi belli yerlerden teşvik alan stratejik eylemlere katılımı, örgütün uluslararası siyasi stratejilerin odağında özel bağlantılarının bir yansıması görünümündedir.

Örgütün kapalı bir siyasal aktör olarak harekete geçmesi, Türkiye'nin bazı iniş-çıkışlarla birlikte "din-toplum-devlet" ilişkilerinin normalleşmesi dediğimiz iki binli yıllarla birlikte hızlandı. AK Parti iktidarıyla birlikte dinî cemaatlerin üzerindeki baskılar tedricî olarak kalkarken, dindar memura, dindar siyasi aktöre yönelik sistemli takibatlar da sona erdi. Kamusal alanda bir cemaate, tarikata ya da dinî bir gruba mensubiyetten kaynaklanan sorunlar nispeten azaldı. Esasen 1980'lerden sonra değişen toplum ve kültür yapısı karşısında geleneksel İslami gruplar, tarikat ve benzeri cemaatlerin etkisi azalmıştı. Bir bakıma bu süreçte, hiyerarşik ve planlı çalışan örgütsel yapısı sayesinde sivil ve sosyal alanda boşluğu dolduran en büyük hegemonik güç olarak Gülenist yapı kalmıştı. Türkiye özellikli iki binli yıllarla birlikte laikçi ulusalcı toplumsal çevrelerle dindar muhafazakâr kesimler arasında sarsıcı siyasal çatışmalar ve gerilimlerle dolu geçen bir demokratikleşme ve normalleşme sürecine girmişti. Bu dönemde değişim sürecini engellemeye yönelik jakoben tavırlar, kendini en çok tehdit, askerî darbeye çağrı ve girişimlerinde gösteriyordu. Ancak bu süreçte devletin kritik noktalarında yer tuttuğu anlaşılan Gülenist örgütün devlet içinde aktif yayılma, ele geçirme ve kadrolaşma stratejisi takip ettiği anlaşıldı.

Kamusal alanda sürekli olarak "siyaset üstü" bir hareket olduğunu vurgulayan Gülenist yap1, özellikle 2000'lerden sonra, kamusal alanı ve siyasi gündemi belirlemeye yönelik operasyonlarla siyaseti dizayn etmeye çabalamıştır. Gülen, AK Parti iktidarı döneminde Anayasa Referandumu tartışmalarında çok açık bir şekilde tartışmalara katılmıştır. Cemaatin siyasi stratejisi her seçim öncesi genellikle iktidara veya “en güçlü”den yana projeler içinde yer almaktır. Gülen'in 12 Eylül 1980 askerî rejimine ve 1982 Anayasası'na karşı çıkmaması ve sonraki yıllarda Turgut Özal, Tansu Çiller ve nihayet Bülent Ecevit ile yakın ilişkiler kurması, temelde siyasal otorite ile ilişkilerini iyi tutmak istediğinin açı örnekleridir. Bütün bu somut göstergeler sonrasında, Gülenist yapının 2007-12 yılları hariç, aynı anda birçok siyasi partiyle ilişkisi olan ama asla siyasetler üstü olmayan bir hareket olarak tespit edilmesi yanlış olmaz (Çakır \& Sakallı, 2014, s. 29). Burada belki de cevabı aranması gereken soru şudur; kendini aktif siyasetin dışında ve apolitik temelde tanımlayan bir yapı, pratik düzeyde nasıl olup da bu denli siyasallaşmış ve siyasi gündemin aktörü olmayı başarmıştır? Elbette burada cemaatin siyasallaşmasından kastımız, meşru siyasal zeminde normal bir siyasi aktör olarak katılım değildir. Gülenci yapıda ortaya çıkan siyasallaşmanın niteliği, normal siyasi süreçler ve argümanların dışında, dolaylı ya da siyaset dışı araçlarla meşru iktidarlar ve kamuoyu üzerinde hegemonya oluşturmaya yönelik bir eğilimi temsil etmektedir. 
Gülenist yapının çok önceden başladığı bu kamusal ve resmî kurumlarda stratejik güç ve hegemonya oluşturma pratiği, AK Parti Hükûmetleri döneminde de sürdü. Özellikle sivil ve kamusal alanda devşirdiği sosyal ve kurumsal sermayesini kendi lehine genişletecek politikalar konusunda AK Parti iktidarına yaklaştı ve buradan azami ölçüde yararlanmayı bildi. Kritik kurumlardaki örgütlenmesinin ve küresel desteklerinin verdiği cesaretle, tahakkümcü siyasetini daha da derinleştirerek, tehlikenin farkına varan ve bu anlamda bazı önlemlerle karşı harekete geçen meşru AK Parti Hükûmeti'ne karşı operasyonlar için düğmeye bastı. 17-25 Aralık olayı AK Parti iktidarına karşı örgütlü yapının düzenlediği bir yargı darbesi olarak Gülenist yapı için artık çatışma ve çöküş olarak adlandırılabilecek yeni dönemin başlangıcı olur.

\section{Çatışma Süreci ve Darbeci Teamüllerin Açığa Çıkması}

Gülenist yapının kamusal alanda gayri meşru bir siyasal aktör olarak rol kapma ve toplumu dizayn etme eğiliminin 1995'ten sonra aşamalı olarak devreye girdiği söylenebilir. Bu yönelim, özellikle 1995'ten 28 Şubat 1997’ye kadarki süreçte, Gülen'in merkez sağ ve sol siyasetçilerle yoğun ilişkilerinde ortaya çıkmıştı. 17 Aralık 2013'ten sonra örgüt, bilinen iktidar ve resmî otorite yanlısı pragmatist siyasetinden sözde muhalif, çatışmacı bir siyasete doğru evrilerek çok tartışmalı ittifaklarla ve tartışmalarla gündeme geldi; bu arada bazı yargısal süreçlerin ve davaların konusu olmaya başladı. Söz konusu muhalif tavır, açık siyasi süreçlerden daha ziyade kendi medyasında, cemaat yapılarında ve bir kısım sivil siyasi örgütler aracılı̆̆ıla, ya da emniyet, yargı ve finans çevrelerinde illegal operasyonlarla ortaya kondu. Örgütün özellikle 1995 sonrasında derinleşen ve alenileşen siyasallaşma sürecini kendisiyle ilgili tehdit algısına karşı bir savunma refleksi olarak açıklayanlar bulunsa da, bu eğilimin gerçekte yapının kamusal alanda nüfuzu ve siyasal otoriteyi eline geçirmeye yönelik örtülü hedefiyle ilgili olduğu da ifade edilmiştir (Bayramoğlu, 2014).

Demokratik süreçlerde AK Parti ile Gülenist Hareket'i yakınlaştıran sosyolojik etken, yeni İslami orta sınıfların her iki kategori içinde en geniş toplumsal kesimi oluşturmasından kaynaklanır. Bir başka deyişle, sosyo-ekonomik bakımdan 1980 sonrası süreçte gelişen yeni İslami orta sınıflar gerek siyasal alanda gerekse dinî alanda neo-liberal eğilimleriyle zaten küresel dünyanın bireyci, tüketimci ve çoğulcu değerlerinde birleşiyordu. Gülenist yapı ve AK Parti geniş anlamda, gerek sosyal taban bakımdan gerekse yeni kültürel iklim bakımından bu yeni İslami burjuvazinin ekseninde şekilleniyordu. Paralel yapının küçük bir cemaatten devasa örgütlü bir hareket haline gelmesi ve hegemonik gücü ele geçirmesi, ne sahip olduğu dünya görüşü ve dinî yorumu ne de tek başına AK Parti'nin siyasal etkisiyle açıklanamaz. 
Zira yetmişlerde ortaya çıkan cemaatin Türkiye'nin içinden geçtiği toplumsal ve siyasal kırılma aşamalarında ve kritik evrelerinde durumu sürekli kendi lehine çevirecek oportünist ittifaklarla yoluna devam ettiği bilinmektedir. Neticede hareket tam da bu süreçte Türkiye'de eğitim, medya, sosyal, kültürel ve ekonomik ağlara dâhil olmak isteyen yeni dindar orta sınıflar için oldukça büyük potansiyel taşıyan bir yapı olarak palazlandı.

Gülenist yapı ve AK Parti, gerçekte farklı İslami söylem, anlayış, değer ve sembollere, değişim konusunda zit yöntem ve stratejilere sahip olmalarına rağmen, tarihsel ve toplumsal konjonktürün etkisiyle 2011'e kadar stratejik bir yakınlaşma içerisinde oldular. Bir yanda muhafazakâr, yeni orta sınıfların ve geniş toplumsal kesimlerin desteğini almasına rağmen, resmî kurumlarda ve bürokraside yeterli yapılanması ve desteği bulunmayan kırılganlığıyla, laik-seçkinci çevrelerin dışlayıcı, darbeci ataklarıyla boğuşan AK Parti; diğer yanda eğitimden medyaya, sağlıktan yayıncılığa, finanstan bürokrasiye geniş bir kurumsallaşma ve örgütlenme ağına sahip olan, ancak siyasi aktörler ve temsiliyet açısından yetersiz olduğu için resmî alandan gelebilecek risklerden korunmak isteyen Gülenci hareket... Lakin askerî ve idari soruşturmalara konu olan yapıyla irtibatlı bazı durumlar Gülen hareketinin emniyet, yargı ve silahlı kuvvetler gibi devlet kurumlarında kadrolaşma eğilimi içinde olduğunu göstermiştir (Çakır, 1992, s. 104). Cemaat, yargıda ve emniyet teşkilatında sahip olduğu belirtilen örgütsel gücüyle, 2005 sonrasında Türk Silahlı Kuvvetleri'ne yönelik yürütülen bir stratejinin baş aktörü olarak tartışmaların odağında yer aldı. TSK'nın siyasette ve yargıda ağırlığının olduğu başlangıç döneminde AK Parti ve Cemaat ilişkisi çok güçlü değildi. Ancak özellikle Abdullah Gül'ün cumhurbaşkanı adaylığına karşı 27 Nisan E-Muhtırası, türban krizi ve AKP’yi kapatma davası gibi antidemokratik süreçler, AK Parti ile Cemaat arasındaki arızi yakınlaşmanın zeminini oluşturdu (Çakır \& Sakallı, 2014, s. 15-18, 25-26).

Söz konusu yakınlaşma sürecinde, devlet kurumlarının demokratikleşerek reforme edilmesi ana gündem maddesi olmuştur. Reform konusunda sağlanan ittifak, baskıcı seçkinci oligarşinin geriletilmesinde etkili sonuçlar ortaya koymuş, Gülenist yapı açık bir şekilde bir siyasal partiye angaje olarak yakınlaşmış, bunun karşılığında ise sosyal, ekonomik ve sivil toplumda genişlemesinin yanı sıra, kritik devlet kurumlarında yaygın ve derin bir kadrolaşma firsatı bulmuştur. Ancak yakınlaşma sürecindeki ilişkiler, 7 Şubat 2012 MİT Olayı ile yeni bir evreye girmiştir. AK Parti ve Cemaat arasındaki siyasal gerilim, dershanelerin kapatılması meselesi ve 17 Aralık 2013 Yargı Darbesi ile tamamen açı̆ga çıkar (Duran, 2014a). Bu dönemle birlikte, kendi medyasından ve Cemaat'in illegal örgütlenmesinden hareketle keskin ve agresif bir muhalefete soyunan yapıya karşı, AK Parti iktidarı kendi tanı- 
mını siyasi dolaşıma sokarak, bu olguyu "paralel yapı" olarak mahkum etti. Paralel Yapı isimlendirmesi, bir bakıma hareketin siyasi yapılanmasını ve yarg1, emniyet ve bürokrasideki örgütlenmesini hedef alırken, cemaatin alt kesimlerindeki bağlılarını ayırt etmeyi amaçlıyordu.

Dershanelerin kapatılması tartışması ile büyüyen ve 17 Aralık Darbesi ile zirveye çıkan çatışma süreci, Gülenist örgüt açısından artık yeni bir döneme geçişi simgeler. Bu dönemde AK Parti iktidarı tarafından kesin bir dille hareketin devlet kurumlarındaki yapılanmasına karşı etkin bir mücadele başlatılacağının ifade edilmesi, yeni çatışma eksenini doğurmuştur. Hükûmet, hareketle ilgili bütün ilişki ve destek noktalarını kesme kararı alırken, Gülenist yapı savunmaya yönelik yeni söylem ve ittifaklarla çare arayışına girdi. Harekete mensup medya yayınlarında ise iktidarın giderek başlangıçtaki çoğulcu liberal ve demokrat tutumlarından uzaklaşarak Siyasal İslamcı bir çizgiye kaydığı, AK Parti'nin özellikle Orta Doğu siyasetinde İslamcı İhvan siyaseti izlediği, Irak ve Suriye'de mezhepçi politikalarla IŞİD gibi dinci terörist grupları desteklediği ya da destekliyor göründüğü iddiaları alttan alta işlendi, dış basında hükûmet üzerinden adeta Türk Devleti'ne savaş açıldı. Türkiye Cumhuriyeti'ni dışarıda itibarsızlaştırmaya yönelik eylemleriyle "ihanet" kavramının içerisinde kolaylıkla yer bulabilen örgüt, bu tür bir siyasetle nerelere savrulabileceğini gösterdi. Örgütün bu süreçte sergilediği muhalif dil giderek sertleşti ve sözde bazı dinî kavramları siyasi içerikle dönüştürmeye çalıştı. Hatta İslam tarihinde mağduriyeti temsil eden bazı olguları bile kendisiyle özdeşleştirmeye teşebbüs ederek Ehli Beyt'in mağduriyet ve mazlumiyetini kullanmaya kalkışması dikkat çekiciydi. Devletin önemli güvenlik kurumlarındaki örgütlenmenin mahrem dinlemeler, kayıtlar, kumpaslar ve dış güçler hesabına casusluk boyutuna varan operasyonlara bulaşması, Gülenist hareket tarafından hiçbir zaman için reddedilen eylemler olmadı. 17 Aralık sonrası Gülen'in Mülaane dediği ama kamuoyunun ve İslami grupların beddua olarak tanımladığı olay ise şiddetli kopuşun (Duran, 2013) özel bir sembolü olmuştur. Gülenist yapıyı tarihsel gelişim sürecinde hiçbir zaman kendinden ve kendi içinde saymayan diğer İslami gruplar ve hareketler de bu süreçte keskin bir şekilde paralel yapıyı reddettiler.

\section{Çatışmadan Çözülmeye Gülenist Yapının Bitişi}

17-25 Aralık sürecinden sonra Gülenist yapı, özellikle yerel seçimlerde ve Cumhurbaşkanlığı seçimlerinde, AK Parti'ye karşı muhalif bulduğu her kesimle ittifaklara girişmiştir. Gülenist yapının bu tavrı, diğer dinî grup ve cemaatlerle birlikte sağ muhafazakâr partilerin de ağır bir şekilde eleştirdiği husus olmuştur. Paralel yapı, uluslararası alanda AK Parti'nin dış politikada siyasal İslamcılık üzerinden bir 
politika yürüttüğüne dair propaganda yaparak Türkiye'yi zor duruma düşürmeye yönelik faaliyetler içinde oldu. İçeride ise AK Parti'nin 17 Aralık'tan sonra çıkardığı bir dizi yasa ve uygulamalarla aslında "İslami söylemli Kemalist bir parti"ye dönüştüğünü yayarak İslami kesimi maniple etmeye çalıştı. Bir başka deyişle, dışarıda “1lımlı İslam” rolüne sığınarak meşru Türk Hükûmeti’ni sıkıştıracak her türlü propagandayı kullanan paralel yapı, içeride ise İslami grupların hassasiyetlerini suistimale yöneldi. Hareket gerek İslami hassasiyetler ve anlayışlar üzerinden gerekse demokratik gelenekler ve teamüller bakımından AK Parti'nin zayıf olduğunu düşündüğü konularda topyekûn saldırıya geçti. Bu süreçte, AK Parti’nin Gülenist yapıyla mücadelede hareketi bir bütün olarak karşısına almamaya çalıştı̆̆ı, özellikle "ibadet”le meşgul olduğu düşünülen tabanı ayrı tuttuğu görüldü. Zira genel kabul gören yaklaşıma göre, cemaatin tavanı "ihanet", ortası "ticaret", tabanı ise "ibadet"le meşgul bir yapı olarak tanımlanıyordu. Bu ayrımın etkisi bilinmemekle birlikte, 17 Aralık'tan sonra, örgütün doğrudan yapısı içinde yer almayan sempatizan kitlesinde kısmi bir çözülme ve dağılmadan söz edilebilir.

Gülenist yapının 17 Aralık sonrasında AK Parti iktidarına karşı her açıdan yoğun bir muhalefet sergilediği, çatışmacı bir stratejiyle yeni bir teo-politik söyleme sığındığı görülür. Duran'a göre, bu çatışmada kullanılan araçlar ise ilk defa İslami gruplar ve hareketler açısından sıkıntı verecek argümanlar görünümündedir. Burada örneğin, bir yandan yargı, emniyet istihbarat angajmanlarına sahip çıkılmakta, diğer tarafta dinî söylemlerle karşılık verilmeye çalışılmaktadır. Dinsel görünümlü örgütün siyasal alana tasallutu, İslamcı aydınlar tarafından yeniden laikliğin konuşulması ve tanımlanması talebini uyandırmıştır. Diğer taraftan, bu mücadelenin Gülenist yapı açısından esas etkisi ise paradoksal bir şekilde aşırı siyasallaşmasına yol açmasıdır. Siyasallaşması alenileşen bir cemaatin, din dilinde de seçkinci-ötekileştirici bir söylemle öne çıkması söz konusudur. Yapının siyasallaşmış operasyonel unsurları ve kapalı örgütsel yapısı, İslamcı aydınlar, cemaatler ve devlet ilişkisinde yeni bir laiklik teorisi ve pratiğini tartışmaya açmıştır (Duran, 2014a).

Gülenist hareketin 17 Aralık 2013 sonrasında, iktidar olan AK Parti'ye karşı yürüttüğü irrasyonel saldırgan muhalefeti, dinsel temelli bir grubun inanç yapısıyla birlikte bütün faaliyetlerinin tartışılmasına yol açmıştır. Gülen'in tevazu altında örtülü bir kibri temsil ettiği ve mehdici bir söylemi teşvik ettiği gibi bazı eleştiri unsurları öne çıkmıştır. Bu çerçevede, dinî grupların finansal faaliyetleri, dinî adanmışlığın ve hayır çalışmalarının güvenilirliği eleştiri konusu olmuştur. İslami hassasiyetlere sahip aktörlerin bu süreçte çok yönlü bir iktidar yozlaşması yaşadığına ilişkin tartışma, özellikle İslami entelektüeller arasında gündem teşkil etti. Bu durumu bir içe çöküş olarak yorumlayan Duran, sürecin sonunda, İslami hareketlerin 
tabanını oluşturan gençlerin ya bireysel sufi tepkiler ya da Selefi tepkiler arasında savrulma ihtimaline de dikkat çekmiştir (Duran, 2014).

Gülenist yapının başlangıcından bu yana yapılan eleştirilerin niteliği ve yönü, süreç içerisinde yaptığı dönüşümlere göre değişiklik göstermiştir. İlk döneminde 28 Şubat Darbesi'ni desteklemesi, İngilizce eğitim veren okullar açarak küresel güçlerle iş birliğine gitmesi, ehli kitap perspektifiyle İsrail'e yakın durması gibi konularda eleştiriye uğrarken (Aktaş, 2013, s. 85); ikinci ve üçüncü dönemlerde sivil alanda tahakküm, karşı-kamusallık ve dinlerarası diyalog gibi siyasi ve dinî içerikli tenkitlerin odağında yer almıştır. Yine bu dönemde sırlı masonik iç yapılanması, takiyyeci politik ve dinî argümanları, kritik kurumlara sızma stratejisi sosyopolitik gündemden düşmemiştir.

Dünyanın dört bir yanına yayılan okulları aracılığıla küresel bir fenomene dönüşen Hareket'in ideolojik söylemi de diyalogcu bir dile kaymıştır. Bu bakımdan ulusal ve uluslararası siyaset ekseninde ortaya çıkan ihtilaflarda, yapının millî hedeflere bağlılığı hep şüpheyle karşılanmıştır. Yine bu denli bir sivil, sosyal ve kurumsal hayata yayılan ve bürokratik kadrolarda güç temerküzü yapan bir hareketin kazandığ1 özgüven, kendisi gibi dinî hassasiyetleri olan muhafazakâr bir hükûmetle bile iktidar savaşına girmesine yol açmıştır.

Harekete yapılan temel eleştiri unsurlarından birisi de içsel yapısındaki kapalılıktır. Cemaat başlangıcından itibaren piramidal, çok katmanlı, katı-hiyerarşik ve merkezî yapılanma ile örgütlenmiştir. Bazı araştırmacılar, bu özellikleri dikkate alarak, örgüt yapılanmasının masonik karakterde olduğunu ifade etmektedir. Cemaatin bu şeffaf olmayan hiyerarşik piramidal yapısı kamuoyu tarafından bilinmemekte, ancak sonradan ayrılan bazı üyelerin açıklamalarında ifşa olmaktadır. Dışarıdan görünmeyen kapalı yapısına karşılık hareketin kamusal alandaki temsili, sivil toplum kuruluşu gibi çalışan bir hizmet hareketi şeklinde lanse edilmiştir (Akçay, 2014).

Gülenist harekete yapılan kritiklerden bir diğeri de, "seçilmişlik sendromu" kavramıyla ifade edilmektedir. Gülen'in pek çok konuşma ve vaazında rastlanan ve kendi cemaati ve bağlıları için adeta seçilmişliği ifade eden telakkisi dikkat çekicidir. Bu noktada, cemaatin kendinden başkasını görmezlikten gelmesi, diğer bütün Müslümanların değerini Cemaat'e hizmetle ölçmesi ve hasım bildiklerini bertaraf etmesi, onun seçilmişlik algısından güç almaktadır (Öztürk, 2014b). Hareketin uluslararası ölçekte yaygın bir ağ oluşturması, onu hem uluslararası güçlerle ittifak ve iş birliğine hem de Türk Devleti'ne karşı bağımsız politikalar izleme eğilimine sokmuştur. Mavi 
Marmara olayında, İran'la ilişkilerde, Orta Doğu politikalarında, Gazze meselesinde sürekli olarak hükûmete karşıt bir politika izlemiştir. Uluslararası bir güç konseptinde geriye ittiği millî ve dinî hassasiyetleri nedeniyle, geleneksel Sünni kodlardan uzaklaştığ1 (Duran, 2013) konusunda bir mutabakat oluşmuştur.

Son döneminde ortaya çıktığı üzere, hareketin başarıya ve sonuca odaklı faaliyetlerinin ve kadrolaşma gayretlerinin engellenmesi durumunda agresif bir siyasi dile yönelmesi, gayri meşru araçları kullanıma sokması dikkat çekici bulunmuştur. Gülenist gruba yönelik suçlamaları Gülen'in bir beddua söylemiyle reddetmeye çalışması, grup medyasının ise sınırları belirsiz bir tepkisellikle muhalefet yapmaya kalkışması, hareketin son dönemine özgü bir anomali olarak şekillenmiştir. Ancak grubun "devlet içinde devlet" olarak algılanmasına yol açan örgütlülük ve faaliyetlerine müdahalelere radikal cevaplar vermeye çalışması, mücadelenin aslında "yolsuzluklara karşı" yapıldığı iddiası hegemonik eğilimleriyle ilgili olumsuz bir kanaat uyandırmıştır (Duran, 2013). Paralel yapının, medyasında izlenen dinî temalı agresif muhalefet dilini özellikle sosyal medyada geniş bir ağ etkisiyle kullanması, siyasal mücadelede aktif bir muhalefet partisi gibi organize olması tepkilere neden olmuştur.

Diğer İslami gruplardan Gülenci yapıya yöneltilen temel eleştiri, Hareket'in sivil toplumda ve devlet kadrolarında firsatların değerlendirilmesi rekabetinde adaletsiz bir mücadele yürüttüğüne ilişkin kabuldür. AK Parti iktidarı döneminde Cemaat'in bazı avantajlar kazanması aslında diğer İslami gruplar arasında bir rahatsızlık yaratmıştır. Eğitim ve emniyet kadrolarında yapıya mensup olanların hızla yükselerek kontrolü ele alması, bulundukları yerlerde diğer grupları tasfiye etmeleri soruşturmalara konu olmuştur. MİT Krizi ile devlet içindeki Hareket müntesiplerinin kendisine operasyon yapma noktasına ulaştığı kanaatine ulaşan ve bu örgütlenmeyi yok etmeye çalışan AK Parti iktidarı, diğer İslami grupların Gülen Grubu rahatsızlığını kendisine desteğe çevirmiştir (Duran, 2013). Cemaat ve AK Parti iktidarı arasında şartların desteklediği fiilî birliktelik durumu, esasen her iki grubun da samimi bir iş birliğini göstermiyordu. Bu durum, içten içe süren çekişmelerle süreç içerisinde kırılma noktalarında iyice açığa çıktı. Böylelikle "yapının kadrolaşma hırsı ve güç toplama arzusunun belli bir sınırı olmadığı, üstelik bu kadrolaşmada devlet içinde sadakat problemi yarattı̆̆ı" en çok vurgu yapılan husus oldu.

Cemaat'in bürokraside ve devlet kurumlarındaki kadrolaşmasında uyguladı̆̆1 dinî temelli takiyye stratejisi, geleneksel Sünni anlayışta karşılığı olmayan bir tavırd. Bu konuda, Cemaat'in takiyye pratiği, neredeyse Sünni sabır siyasetinin ötesine geçerek, Şia'nın takiyye siyasetine yaklaştı. Gülen'in dinî bilgi kaynağı olarak rüyaları kullanması, takipçileri açısından dinî bilginin hurafeleşmesi, mistikleşmesi dediğimiz bir anlayışın kabulüne de yol açtı (Duran, 2013). Kitleleri yönlendirme- 
de tercih edilen batıni nosyonlu dinî bilgiyi kullanma eğilimi, Sünni İslam geleneğinde meşru görülmediği için eleştirildi. Kabul edilmesi gerekir ki bu eğilim, hem Gülen'in kendini atfettiği Nurcu gelenekte hem de yeni dinî hareketlerde kitleleri cezbetmede rağbet gören bir tutumdur. Yine aynı şekilde, Nurcu geleneğin karakteristiklerinden biri olan "mehdici” düşünce Gülen'in söyleminde zirveye ulaştı ve yapı adeta kültik bir dinî grup formuna büründü.

Gülenist yapının değişim stratejisinin ekseni güçlü olmaya, dolayısıyla gücü elde etme uğrunda taktikler geliştirmeye dayalıdır. Güç temerküzü için, siyasete mesafeli gibi görünse de fiiliyatta hep siyasetle içli dışlı olunmuştur. Gülen dinî kavramları ve terminolojiyi güç temini için nasıl maniple ettiyse, siyasi alanı ve süreçleri de aynı şekilde kullandı. Siyasete meşru araçlarla girip muhalefete düşme riski almaktansa, dışarıdan ya da bürokratik nüfuz yoluyla oportünist taktiklerle "sürekli kazanma" tercih edildi. Gülenci yapının geldiği son aşamada önünde sert muhalefet, düşük yoğunluklu mücadele, partileşmek ya da sivil cemaat olarak devam etmek gibi seçenekleri vardı. Partileşme seçeneğini dışta tutan yapı, daha çok o dönemde Başbakan Recep T. Erdoğan'ın şahsına ve AK Parti'ye karşı düşmanca bir pozisyon alarak yoluna devam etme kararı aldı (Yanık, 2014). Grup medyasının yayınlarında, fikir ve din önderlerinin yorumlarında, hareketin kendini çeşitli sosyal ve siyasal problemlerin kaynağı olarak gördüğü iktidara karşı savaş açtığı görüldü. Ancak yapısal bakımdan siyasetin herhangi bir kurumsal temeline sahip olmayan bir hareket olarak örgütlü yapı, açık kurumsal denetime tabi olmayan kapalı organizasyonuyla inandırıcı olmaktan uzaktı. Bu durum, hareketin sosyal sermayesinde büyük bir aşınma ve erimeye yol açtığı gibi, sonuçları bakımından hesap dışı kalan bir hareket olarak dönüşümünün nereye doğru olacağını gösterdi. Öte yandan Gülenist yapının sivil, sosyal, kurumsal alandaki güç kaybı, sempatizan ve mensuplarının hareketi terk etmeye başlamasıyla nasıl bir yapısal dönüşümle karşılaşılacağı ilgi konusu olmuştur. Lidere bağlı bir hareket özelliği taşıması grubun geleceği konusunda belirsizlikler üretmiş, örgütün sözde bir dinî grup olarak varlığını meşruiyet çizgisine çekebileceği bir sosyal ve kamusal zemin de kalmamıştır. Gülenist paralel yapı, siyasal alana müdahaleyi siyasal olmayan araçlarla gerçekleştirirken, siyasetin kendisini meşruiyet sınırlarına çekme davetini dikkate almadı. İllegal ve ezoterik örgütlenmesini bir ihanet modunda, uluslararası güçlerle birlikte Türkiye üzerinde baskı unsuru olarak kullanmaya kalkıştı. Örgütsel yapı olarak demokratik olmayan unsurlarla meşru siyasal bir iktidarı gayri meşru araçlarla devirmek için darbeci yöntem ve araçları kullandı. 


\section{Sonuç ve Ek: Darbe Girişimi ve FETÖ`}

Gülenist paralel yapı, başlangıçta Nurcu geleneğe dayanmakla birlikte, süreç içerisinde "güç"ü eksen alan stratejisiyle dilini, metinlerini ve taktiklerini değiştirerek müstakil bir hareket haline gelmiştir. Hareket zaman içerisinde dinî bir gruptan ziyade sivil, sosyal ve ekonomik boyutlarda geliştirdiği kurumsallaşma ile daha çok sosyal bir hareket formunda yapılanmış, ancak kapalı, sivil ve şeffaf olmayan boyutunda ise iç halkalarını kritik devlet kurumlarına sızma amaçlı yönlendirmiştir. Paralel yapının sosyal, eğitimsel ve finansal kurumlarda gerçekleştirdiği yayılma stratejisi, sınırların dışına taşarak dünyanın dört bir yanına yayılan okullar aracıllğıyla küresel bir düzeye ulaşmıştır. Yapının özellikle eğitim, finans ve medya alanındaki ilişki ve görevlerinin belirsiz küresel ağ sistemi haline gelmesiyle, dinî ve ideolojik söylemi de liberal diyalogcu bir dile dönüşmüş, ulusal ve uluslararası siyaset bağlamında ortaya çıkan ihtilaflarda ise millî hedeflere bağlllığı daima şüphe içermiştir. Öte yandan, kamusal alandaki hegemonyasının dışında resmî alanda da emniyet, yarg1 ve ordu gibi devletin güvenlik kurumlarına sızarak devşirdiği örtülü gücünü demokratik süreçlerde iktidar olmuş bir hükûmete karşı kullanmaya tevessül etti. $\mathrm{Bu}$ çerçevede örgütün kamusal alanda kendisini kültürel, eğitimsel, finansal alanlarda faaliyet gösteren bir sivil toplum kuruluşu gibi göstermesine rağmen, siyaset dışı araçlarla meşru bir yönetimi alt etmeye çalışması, özgürlükçü liberal kavramlarla maskelediği sivil toplum hareketi olma iddiasını da geçersizleştirmiştir.

Gülenist yapi, kültürel ve sosyal alanda dernekleşme ve vakıflaşma gibi araçlarla yaygınlaşmasına karşın, iç yapisında ya da teşkilatlanma biçiminde bir şeffaflaşma, kontrol ve denetime açık olmaması nedeniyle resmî topluma ve diğer dinî cemaatlere güven telkin etmemiştir. Hareketin faaliyet alanında "himmet ve hizmet" adı altında toplanan bağış ve yardımlar şeffaf ve denetime açık bir şekilde yapılmadığı gibi, yardımlar, bağı̧̧ ya da himmetin harcanma yerleri konusu hep belirsizlik ve güvensizlik pozisyonuyla dikkat çekmiştir. Diğer yandan, bir sivil hareketin ya da cemaatin kapasitesini aşacak biçimde çok büyük bir finansal kaynağın informel yollarla harekete geçirilmesi, yapının küresel finans sistemi içinde dâhil olduğu ağ ilişkilerini ciddi biçimde tartışmaya açmıştır. Paralel yapının en önemli desteğini iş adamlarının özellikle "himmet toplantıları"nda bağışlarla sağladığı kaynağı ve harcama odağı belirsiz büyük ölçekli sermayenin uluslararası dolaşımda kimlere ve neye hizmet için kullanıldığı sorusu daima açık kalmıştır.

9 Bu metin, 2014 Kasım'ında bildiri olarak sunuldu. Ancak bu süreçte Türkiye, paralel yapının darbeci terör örgütüne evrildiği bir süreci yaşadı. Metin kitap yayınına verilmeden önce, örgütün bu son durumunu bir ek olarak kısaca değerlendirmeyi uygun bulduk. Esasen FETÖ’nün 15 Temmuz Darbe Girişimi ve akabindeki gelişmeler, ayrı bir çalışma konusu olacak kadar önemlidir. 
Gülenist yapı, kendini en çok eğitim alanında yaptığı faaliyetlerle, uluslararası düzeyde açtığı okullarla temsil etme yolunu seçmiş, bu bağlamda bir eğitim hareketi imajına sarılmıştır. Ancak eğitim sektöründe yer alan hazırlık kursları ve dershaneler, özel okullar, kolejler ve özel üniversiteleriyle toplumun geniş kesimleriyle irtibat kuran örgüt, bu okulları öncelikle karşı-kamusallığın inşasında araçsallaştırmıştır. Diğer yandan, aynı kurslar ve okulları illegal örgütlenmede güvenlik ve emniyet kurumlarına sızarak ele geçirme stratejisi için de kaynak olarak kullanmıştır. Uluslararası düzeyde faaliyet alanı olan yurt dışı okullarının misyonu ve bu okullarda verilen eğitimin niteliği hakkındaki belirsizlikler ve şüpheler hiçbir zaman cevabını bulmamıştır. Bu okulları adeta uluslararası ticari ve kültürel faaliyetler için bir açılım kaynağı gibi göstermeye çalışan örgüt, adanmışlık düşüncesiyle cemaat mensubu öğretmenlerin istihdam edildiği ve dünyaya yayıldığı merkezler olarak tanımlamıştır. Bulundukları ülkelerdeki elit çevrelerin çocuklarını çeken okullarda eğitim dilinin İngilizce olması, bazı ABD pasaportlu yabancı öğretmenlerin çalı̧sması ve eğitimin seküler karakteri, ne cemaat mensuplarınca ne de okulları destekleyen muhafazakâr kesimlerce pek önemsenmemiştir.

Örgütlü dinî yapının din anlayışı ve refleksleri, süreç içerisinde daima Gülen'in söylemleriyle yön değiştirmiş, ancak bu söylemin zaman içerisinde gösterdiği zikzaklar tartışmalardan hâlî kalmamıştır. Bu bağlamda cemaatin özellikle küresel bir aktör olarak rol aldığı diyalog faaliyetlerinde İslam'ın tevhid ve hakikat iddialarını geri plana atacak bir politika izlemesi, yapının İslami itikat sistemine yönelik bir inanç darbesi olarak okunmuştur. Öte yandan, Gülen'in inşa ettiği din dilindeki ezoterik, batıni nosyonla birlikte, karizmatik liderliğin mehdilik beklentisini işleyen gelecek zaman tasavvuruyla ilgili temsiller, diğer İslami grupların dikkatini çekmiş, bu durum Sünni kelami doktrinden köklü bir inhiraf olarak damgalanmıştır.

Gülenci yapı, teorik bağlamda siyasete negatif bir dille yaklaşmasına karşın, örtülü ilişkilerde daima güçlü olanın yanında ve siyasi görüşü ne olursa olsun iktidarlara bitişik bir politika izlemiştir. Bu çerçevede sürekli olarak siyasi konjonktüre uygun pozisyonlar almıs, hatta bu bakımdan muhafazakâr-dindar geleneğe ters düşen kesimlerle geçici ya da daimi ittifaklara bile girebilmiş bir siyasal oportünizm örneği olarak şekillenmiştir. Örgütsel yapı, stratejik hamlelerini hep bir "tedbir ve takiyye" anlayışı içerisinde içselleştirmiştir. Ancak paralel yapı dinî bir grup görüntüsüne rağmen siyasetle paradoksal ve tahakkümcü ilişkisine yönelik sorgulamalara ikna edici cevaplar vermek yerine, bir sivil örgüt ya da siyasal bir oluşum gibi davranarak karşılık vermeye çalı̧̧mıştır. Bununla birlikte dinî nosyonu, toplumun bazı alt kesimlerine ya da statü arayışındaki muhafazakâr çevrelere cazip gelmiş ve ilgi çekmiştir. 
Gülenci yapının sosyal aktör olarak, toplumsal kamusal alanda kurumlara yayılan etkili bir aktör olma isteği, zamanla kendisine hayatiyet veren dinî nosyonun ikincil hale gelmesine yol açmış, bu bakımdan Hareket, kendisi içsel bir sekülerleşme yaşamıştır. Gülenist paralel yapının sivil hareket tanımına uygunluğu tartışmasına benzer şekilde, dinî bir grup olup olmadığı sorusu da hep sorgulama konusu yapılmıştır. Kamuoyunda bilinen ve öne çıkan dinsel grup imajına rağmen, hareketin belli bir dönemden sonra hem kendi tanımlarında hem de faaliyetlerinde bilinen dinî grup tanımlarının dışında örgütsel bir yapıya dönüştüğü açıtıtır. $\mathrm{Bu}$ durumun en önemli sebebi, öncelikle kendi içsel yapısında kapalı masonik bir yapılanma göstermekle birlikte, diğer yandan sivil ve resmî alanda gösterdiği örgütlenme pratiği ile devletin kritik kurumlarını içeriden ele geçirmeye çalışması olmuştur. Gülenist yapı, daha henüz ikinci aşamasında, bir başka deyişle 1980'li ylllarla birlikte dinî bir grup olmaktan çıkmıştır. Sosyal kamusal alanda yapısal güç arayışı, siyasal alanla girift ilişkilere girilmesi, devlet kadrolarında mevki kazanma stratejisi, hareketi bir güç odağ olarak paralel bir devlet ve toplum oluşturmaya teşvik etmiştir. Devlet yapısı içinde illegal örgütlenmesine yönelik yapılan suçlamalara, soruşturma ve araştırmalara karşı grup medyasının ve yazarlarının şüpheleri haklılaştıracak şekilde yapılanları savunmaya geçmesi bu konudaki kanaatleri derinleştirmiş, örgütsel yapı tespitini doğrulamıştır.

Gülenist yapının medya ve sivil toplum alanında toplumun farklı inanç, görüş ve düşünce gruplarına karşı açık ve uzlaşmacı, hoşgörü eksenli bir politika izlerken açık siyaset yapan diğer İslami grup ve cemaatleri dışlaması, bir bakıma kendi hoşgörü ve diyalog söylemiyle çelişse de, genel stratejisi açısından oportünist karakterine uygundur. Bu eğilim, aynı zamanda, yapının uluslararası düzeyde hareketi "Ilımlı İslam"ın temsilcisi olarak gösterme gayretiyle de ilgilidir. Paralel yapı, meşruiyet kazanmak için diğer İslami hareketleri radikal siyasal İslamcilığı örnekleri olarak ötekileştirerek, kendi örgütsel yapısında hiyerarşik, ezoterik mehdici bir anlayışı ikame etmeye çalışmıştır. Yapıyı elinde tutan çekirdek kadro, söz konusu stratejilerle küresel dünyanın yeni güç odaklarına, eğer iş birliği yapılacak ve görev verilecekse gerçek adresin kendileri olduğunu işaret ederek İslam dünyasına yönelik İslamofobik değerlendirmeleri destekler görünmüştür.

Bütün bu özellikleri altında yola önce Said-i Nursi'nin metinlerini esas alarak çıkan Gülenizm, örgütlenme ve kurumsallaşma gücü arttıkça hem müstakil bir hareket haline gelir hem de söylemini, metinlerini ve stratejisini günün şartlarına ve gücün yönüne göre değiştirir. Bir yandan sivil sosyal alanda dernekler, vakıflar, şirketler, okullar ve dershanelerle, diğer yandan bürokratik kritik kurumlarda illegal örgütlenmeyle hegemonik bir güç olma hedefini takip eder. Gücü kutsayan Güle- 
nist yap1, sosyal, kültürel, siyasal ve kurumsal tüm alanlarda iktidarı ve sermayeyi tekelinde tutmak ve kazanımlarını korumak için, inanç ve prensipler yerine takiyye stratejisini izlemiştir. Neticede, masonik örgütlenme tarzıyla ezoterik, batıni, mehdici sapkın bir hareket olarak şekillenen Gülenist paralel yapının, süreç içinde kurduğu hegemonya ile, meşru iktidara karşı darbeye girişen bir örgütlü yapı olarak tarihteki yerini aldığı söylenebilir. Bununla birlikte, yapının etki alanında kalan, bir şekilde çeşitli etkinlik ve faaliyetlerine ilgi duymuş çok sayıda insan, darbe girişimi sonrası, hareketi mahkûm etmiştir.

\section{FETÖ ve 15 Temmuz Darbe Girişimi}

$\mathrm{Bu}$ metin, Gülenci yapının başlangıcından 17 Aralık sonrasına kadar geçen süreçteki dönüşümlerinin sosyolojik analizini 15 Kasım 2014'de İLEM Çalıştayı'nda sunmak üzere hazırlanmıştı. Ancak çalıştaydan sonra bildirilerin kitaplaşma süreci uzadı ve bu arada, tarihler 15 Temmuz 2016'yı gösterdiğinde Türkiye, örgütlü paralel yapı bağlantılı çok önemli bir darbe girişimiyle karşı karşıya kaldı. Bildiri metni tamamlanmakla birlikte, darbeci terörist yapıya dönüşen örgütün $15 \mathrm{Temmuz}$ Darbe Girişimi'ndeki rolünün metne eklenmesinin gerekliliği kendini göstermiştir. Kuşkusuz 15 Temmuz Darbe Girişimi ve darbecilere karşı Türkiye'nin sergilediği tarihî direniş ruhu, müstakil bir çalışmaya konu olacak kadar detaylı ve önemli bir hadisedir. Sürecin ayrıntısına girmemekle birlikte, paralel yapının darbe girişimindeki belirleyici pozisyonunun ve neticede FETÖ adı altında bir terör örgütüne dönüşmesinin tescili kayıtlara geçmeyi gerektirmektedir. Makalenin şekillenmesinde, 15 Temmuz ve sonrası gelişmelerin devam eden sosyoloji bağlamındaki önemi göz ardı edilemezdi.

Millî Güvenlik Kurulu'nun 30 Ekim 2014 tarihli kararında FETÖ/PDY, "millî güvenliği tehdit eden, kamu düzenini bozan, iç ve dış legal görünüm altında illegal faaliyet yürüten paralel yapılanma" olarak tanımlanmıştır. 26 Mayıs 2016 tarihli MGK kararında ise "millî güvenliği tehdit eden bir terör örgütü" olarak kabul edilerek "Fetullahçı Terör Örgütü ve Paralel Devlet Yapılanması" FETÖ/PDY adını alan örgüt, ulusal ve uluslararası işbirlikçi ve destekçilerinin teşvikiyle, 15 Temmuz 2016'da ordu içindeki unsurları aracıllğıyla Türkiye tarihinde örneği görülmemiş bir kanlı darbe girişiminde bulunur. Darbe girişimine karşı Cumhurbaşkanı Recep Tayyip Erdoğan'in halkı demokrasiyi savunmaya ve çağırmasıyla gelişen direnişte 240 şehit ve 2191 yaralı verilerek darbe girişimi önlenir. Sürecin devamında, tarihte örneği görülmemiş bir şekilde, toplumun bütün kesimleri darbeye karşı kenetlenerek 27 gün boyunca kent meydanlarında demokrasi nöbetleri tutar. 
15 Temmuz Direnişi, küresel tüketim kültürüne adapte olmuş modern dünyanın bireyci toplumları için gerçekte çok özel anlamlar taşıyan bir olaydır. Her şeyden önce, demokratik kazanımlarını ve seçimle iktidara taşıdıkları meşru hükûmeti ölümü pahasına, tanklara ve silahlara karşı durarak savunan Türk milleti, modern toplumların sosyolojisi açısından açıklanması güç bir kolektif dayanışma ve mücadelenin örneğini sergilemiştir. Öte yandan, yaklaşık elli yıllık bir süreçte kamusal alanda ve bürokratik kurumlarda örgütlenen bir dinsel yapının ekseninde şekillenen darbe girişimi, dinî oluşumların sosyal ve kültürel alandaki faaliyetlerinin sınırlarına ilişkin tartışmaları da canlandırmış, toplumun dinî gruplara ilişkin algı ve tasavvurlarında önemli kırılmalara yol açmıştır. Öte yandan, yine bu olayla, toplumun kolektif hafızasında yer alan "vatan, millet, özgürlük ve demokrasi" gibi kavramların tarihsel bir direniş ruhuyla kazandiğı yeni anlamlar dikkat çekici olmuştur.

Gülenist paralel yapı darbe öncesinde terör örgütü olarak tescillenirken, 15 Temmuz sonrasında darbeci yapının sahip olduğu medya, eğitim, finans ve sosyal alanda elinde bulundurduğu kuruluşlarla birlikte bütün sivil dernekleri, vakıfları ile sendikalarının da faaliyetlerine son verilmiştir. Örgüt liderinin Türkiye'ye teslimi için $\mathrm{ABD}$ yönetimine resmî müracaatlarda bulunulmuştur; diğer yandan, genelde Batılı ülkelerin ve ABD yönetiminin Türkiye'nin darbeye karşı mücadelesinde gereken desteği sunmaması tarihsel bir refleks olarak kaydedilmiştir. 15 Temmuz Direnişi, İslami tasavvur ve pratiklerin demokratik süreçlere müdahalesi bakımından da önemle işaret edilmesi gereken bir eşik olmuştur. İslam dünyasında darbeci ve terörist unsurlar dinî referanslara sahip olsa da, demokratik süreçlerde olgunlaşan İslami grupların sergilediği tavır da Türkiye pratiği için ayrı özel bir sayfa açmıştır.

Küresel siyasi ve ekonomik güçlerin hegemonik araçlarla dünya sistemini belirlediği bir dönemde, çoğu zaman dişsal müdahalelerle hizaya çekilemeyen ülkeler, içlerinde büyütüp taşeronlaştırdıkları oluşumlarla teslim alınmaya çalışılır. Türkiye, hem tarihinden hem de ait olduğu medeniyetten iktisap ettiği misyonla bölgesinde bir merkez ülke durumuna gelmiştir. Bu sefer, dinî nosyonlu bir yapı eliyle bütün tarihî, İslami ve millî müktesebatıyla birlikte gelecek vizyonu elinden alınmaya çalışılmış; ancak 15 Temmuz, çok geniş bağlamı içinde uluslararası destekli darbe girişimine karşı meydanları teslim alan bir milletin, bilinen sosyolojik kavram ve kuramlarla açıllamakta zorlandığı bir direnişin adı olmuştur. Bu bağlamda 15 Temmuz, Büyük Türkiye Ruhu'nu temsil eden bir eşik olmuştur. 


\title{
Hegemonic Transformation in Religous Organisations
}

\section{From Nurculuk to Post-Nurculuk, Sociological Codes of Gulenist Structures from Community to Organisation ${ }^{*}$}

\author{
Celaleddin Çelik
}

This essay aims to shed light on the transformation and differentiation through processes of the Gülenist community by the sociology of religious groups. The text is not a theoretical text examination, but a scientific sociological analysis of the activities and social transformation of the leader's speech and texts.

The movement had its' intellectual roots in the Nur movement, in the process the movement then had a structural separation even though it shared the same ideological codes and also considerably transformed the Nurcu discourse. The esoteric-mystical, mahdi-messianic codes shared by the movement of Nur in the ideological themes of the movement constitute the basic elements of distinction between it and other religious groups and communities. The Gulenist structure adopts an action strategy that aims to strengthen the social-cultural and educational field, contrary to the identity-based opposing attitudes of religious communities in Turkey with high political sensitivity. However, in a paradoxical way as it spread to the public sphereand adopted illegal organization and power recruitment in bureaucratic and official critical institutions instead of open politics.

Despite the use of civilian institutions that allow transparency and reaching critical mass in the public arena, it has become a paradox of insecurity that the

\footnotetext{
The earlier version of this paper was presented under the title of "From Nurculuk to Post-Nurculuk, Transformation from Community to Parallel Structure" in the "Transformation of Religious Groups in Turkey" workshop organized by ILEM (Scientific Research Associations) in Istanbul on 15 November 2014. After the Gulenist coup attempt in 15th of July the paper was revised with new data and converted into an article.
} 
group made a secret structure specific to secret organizations in its inner rings. This contradiction has not been seen as a significant issue by the sympathizers and the ones who have benefited from the economic, media and educational institutions. Even though the effort to set up an organized religious structure in state institutions has been mentioned from time to time, this situation has not been taken into consideration in public. The ineffectiveness of such protests and outbreaks is explained by the influence of the media and other critical institutions, despite the legal appearance of the movement in the public sphere.

The reasons for this increase in social and cultural capital of the movement have many dimensions. First of all, the fact that the Gulenist Structure had a civilian religious codification in about half a century is remarkable. The ideological framework of the group was shaped by the Nurcu paradigm known as the Risalei Nur tradition in Turkish society, but with the increasing publicity of the movement, the Gülenist structure has been isolated from this tradition. However, activist, positivist, mahdi and esoteric codes that came from the same origin were maintained. The movement, which appeared innovative in an institutional sense and realized it in practice, had been integrated with a hegemonic character along with traditional codes in its intellectual basis. This contradiction has a connection to the form of the charismatic personality that Gülen uses to guide the movement. Gülen, in a way that typically tries to look sympathetic to intellectuals and to people who are open minded, in another way for the traditionalists he is transformed into a mahdi form that can be considered at any time by the savior's mission, in this sense he appears neither as a traditional scholar nor as a modern religious scholar.

Objectively explaining the widespread and effective institutionalization of the movement in the social context requires a number of complex factors to be understood. Above all, as in all religious groups, the structure of the Gülenist Movement has benefited from repressive anti-democratic practices in some stages in the past that Turkey has been through. During the community period of the Gulenist movement, this structure used a common stake with other Islamic groups and justified their illegal actions with these common stakes. The movement, embracing highly pragmatist strategies in this framework, had adopted a non-politic discourse but at the end it has only followed an opportunistic path that kept relations with the power. Through the alliances it has established with political and economic powers, the movement that seized high-level protection and immunity opportunities has used these powers in its favor. The language, which gradually became radicalized with increasing bureaucratic power in the third AK Party era, directed the media to concentrate on the political field and to direct different political actors. 
In addition to the middle classes developing under the neo-liberal economy and politics in Turkey, entrepreneurial traders and industrialists have also been attracted to the movement, young trainers and entrepreneurs who want to move abroad were attracted by the movement's schools and financial ties to international bases. The movement, on the one hand, gained power through state hegemony by their increased hegemony on the public and official scene, and on the other hand it used its schools scattered all over the world as an instrument to mobilize both educated men/women and new business circles who wanted to open up to foreign markets.

The Gulenist structure has influenced global projects such as inter-civilizational dialogues and peace platforms to expand intellectual capital, and inter-religious dialogue to keep the theological capital alive. In all these processes, the movement which does not fit into the definitions of the known community has been directed to show itself as a civil society movement under different names in order to sustain the interests of the masses at large and gain legitimacy in certain social sectors. The secret hierarchical structure of the inner ring, which is publicly known but not taken into account in the civilian public propagation process, has led partly to serious suspicions and inquiries. Although this structure and covert organization sometimes interferes with the judicial process, it is understood that the organization has overcome these judicial process by their deep and effective mechanisms.

The Gulenist structure was defined as a terrorist organization by the National Security Council in June 2016 due to its illegal organization and influence in some operations, and accused of haing a parallel structure under the name FETÖ. The coup d'etat of July 15 has allowed the allegations and illegal organizations that have been spoken at different levels to become valid at the highest level. The ruling party AKP decided to shut down the movement's potential sources created through education, "Dersane" (preperation courses), and that lead the structure, which has been active in military, judicial and security organizations for many years to realize an unprecedented coup attempt in Turkey's history. In Turkey's modernization adventure, an organized religious group was encouraged to use the force that it gained in the public sphere by socioeconomic and sociopolitical pathologies of the time, in order to try to bond to the political sphere, using the tools of power illegally as a hegemonic force. However, the spirit of resistance, which is sociologically difficult to conceptualize, came to the squares in order to defend the country, the fate and the will that it determined the election against the July 15 coup attempt. After this date, while the Gülenist structure is subject to judicial processes, the organization and activities of other religious social groups and communities seem to continue to be at the center of sociological studies and debates. Indeed, at this historical turning point, the social organizations of religious life and the practice of communities [Cemaat] are already giving signs of some significant breaks and transformations in themselves. 


\section{Kaynakça | References}

Acar, Ç. (2016). Dün Cemaat Bugün Paralel Devlet. İstanbul: Profil Yayıncılık.

Akçay, H. (2014). Seküler ve Ruhçu Gelgitler Arasında Gülenizm. Star Gazetesi. http://haber.star.com.tr/acikgorus/ sekuler-ve-ruhcu-gelgitler-arasinda-gulenizm/haber-868918 adresinden erişilmiştir.

Aktaş, Ü. (2013). Bir Kriz Sürecinde Strateji Arayışları. İstanbul: Okur Kitaplığı.

Aktay, Y. (2004). Diaspora ve İstikrar / Bir Bilgi Yapısındaki Kurucu Elementler. Laik Devlet ve Fethullah Gülen Hareketi içinde (s. 177-202). İstanbul: Gelenek Yayıncılık.

Bayramoğlu, A. (2014). Operasyonlar Işığında Cemaatin Kısa Siyasi Tarihi. Yeni Şafak. http://www.yenisafak.com/ yazarlar/alibayramoglu/operasyonlar-isiginda-cemaatin-kisa-siyasi-tarihi-1-55195 adresinden erişilmiştir.

Bodur, H. E. (2003). Moonculuk Hareketi ve Türkiye'de Benzer Bir Cemaat Yapılanmasının Sosyolojik Analizi. KSÜ İlahiyat Fakültesi Dergisi, 1, 13-39.

Çakır, R. (1992). Ayet ve Slogan. İstanbul: Metis Yayınları.

Çakır, R. ve Sakallı, S. (2014). 100 Soruda Erdoğan Gülen Savaşı. İstanbul: Metis Yayınları.

Çobanoğlu, Y. (2012). “Altın Nesil”in Peşinde Fethullah Gülen'de Toplum, Devlet, Ahlak, Otorite. İstanbul: İletişim Yayınlari.

Duran, B. (2013). Gülen Cemaati ve Sünni Kodların Kaybı. Star Gazetesi. http://haber.star.com.tr/acikgorus/gulen-cemaati-ve--7csunni-kodlarin-kaybi/haber-822278 adresinden erişilmiştir.

Duran, B. (2014). Gülen Hareketi ve 17 Aralık Muhasebesi. Star Gazetesi. http://haber.star.com.tr/acikgorus/gulen-hareketi-ve--7c17-aralik-muhasebesi/haber-859175 adresinden erişilmiştir.

Duran, B. (2014a). AK Parti ve Gülen Kavgasında İslami Hareket Nereye Gidiyor. Timeturk. http://www.timeturk. com/tr/2014/02/09/ak-parti-ve-gulen-kavgasinda-islami-hareket-nereye-gidiyor.html adresinden erişilmiştir.

Kömeçoğlu, U. (2000). Kutsal ile Kamusal: Fethullah Gülen Cemaat Hareketi. N. Göle (Ed.), İslamın Yeni Kamusal Yüzleri içinde (s. 148-194). İstanbul: Metis Yayınları.

Kösebalaban, H. (2004). Dost ve Düşman Kazanma / Fethullah Gülen'in Ulusal Güvenlik Kimliği. Laik Devlet ve Fethullah Gülen Hareketi içinde (s. 217-230). İstanbul: Gelenek Yayıncllık.

Öztürk, M. (2013). Cemaat Cemaat midir. Star Gazetesi. http://haber.star.com.tr/acikgorus/cemaat-cemaat-midir/ haber-822271 adresinden erişilmiştir.

Öztürk, M. (2014a). Peygamberin Araçsallaştırılması ve Dinlerarası Diyalog. Star Gazetesi. http://haber.star.com. tr/acikgorus/peygamberin-aracsallastirilmasi--7cve-dinlerarasi-diyalog/haber-843798 adresinden erişilmiştir.

Öztürk, M. (2014b). Gülen Cemaati ve Melez Teoloji, Mehdilik, Takiyye, Müdaracılık. Star Gazetesi. http://haber. star.com.tr/acikgorus/gulen-cemaati-ve-melez-teoloji-3b-mehdilik-takiyye-mudaracilik/haber-840519 adresinden erişilmiştir.

Şentürk, H. (2011). Türkiye'de İslami Oluşumlar ve Siyaset, İslamcılık (2. Baskı). İstanbul: Çıra Yayınları.

Veren, N. (2007). Kuşatma, ABD'nin Truva Atı Fethullah Gülen Hareketi. İstanbul: Siyah Beyaz Yayınları.

Wenzel, N. G. (2012). Postmodernizm ve Din. P. B. Clarke (Ed.), Din Sosyolojisi, Kuram ve Yöntem içinde (s. 281-312). (A. Ayten, Çev.) Ankara: İmge Kitabevi.

Yankaya, D. (2014). Yeni İslami Burjuvazi. İstanbul: İletişim Yayınları.

Yanık, M. (2014). Gülen Cemaati İçin Dört Seçenek. http://www.haber10.com/yazar/prof_medaim_yanik/gulen_ cemaati_icin_dort_secenek-41929 adresinden erişilmiştir.

Yavuz, H. (2004). Kamusal Alanda İslam: Nur Hareketi Örneği. Laik Devlet ve Fethullah Gülen Hareketi içinde (s. 3958). İstanbul: Gelenek Yayıncilık.

Yavuz, H. (2005). Modernleşen Müslümanlar. (A. Yıldız, Çev.) İstanbul: Kitap Yayınevi. 
